\title{
Putting Roman and Canon Law in a Nutshell: Developments in the Epitomisation of Legal Texts between Late Antiquity and the Early Modern Period
}

\author{
Christoph H.F. Meyer
}

\section{Introduction}

"The form and manner in which the sources of Roman law were abused in the Frankish Empire [...] such overestimation of juridically inferior material as is expressed in the preference for the epitomes [...] all this characterises in unambiguous fashion the appalling decadence of Roman law [... ${ }^{\prime 1}{ }^{1}$ In these remarks of Alfred von Halban (1865-1926), one can detect assumptions that shaped legal historians' ideas about epitomes for a long time. Epitomes were viewed as rather primitive reference works that deprived the sophisticated source texts of their originality and jeopardised their later transmission. In fact, they were frequently held to be symptoms of decline. Some aspects of this perception can be traced back to the humanists. ${ }^{2}$ More recent works have judged the epitomes less harshly. However, their improving reputation is only partly due to new insights, ${ }^{3}$ since legal historians have examined the phenomenon of epitomisation only sporadically, that is, only with regard to a small number of specific examples. ${ }^{4}$

1 Halban, Das römische Recht in den germanischen Volksstaaten, vol. 3, 9o. See also Halban, Das römische Recht in den germanischen Volksstaaten, vol. 2, 351. For more on the author, see [Anon.,] "Alfred von Halban". Unless otherwise indicated, all translations are the author's.

2 Accordingly, the philologist Isaac Casaubon (1559-1614) condemned the pestis ... compendiorum et epitomarum confectio. See [Casaubon,] Henrico IV. Franciae et Navarrae Regi Christianissimo, 62. For similar views, see Bacon, De augmentis scientiarum, eds. Spedding, Ellis and Denon Heath, lib. II, cap. 6, 506. The negative perception of epitomes occasionally inspired apologetic remarks. See Olearius, Doctrina theologiae moralis totius, Preface "Auditoribus suis". On the ancient roots of this view, see Mülke, Der Autor und sein Text, 95-108.

3 For a recent, yet traditional view of epitomes, see Meder, Rechtsgeschichte, 108.

4 This applies especially to the Roman law of late antiquity and the early Middle Ages (e.g. D. Liebs, H. Siems) as well as the classical canon law of the High and Late Middle Ages. (e.g. J. Rambaud-Buhot, R. Weigand). See: Liebs, Hermogenians iuris epitomae; Liebs, "'Variae 


\section{Epitomes and Epitomisation}

Before turning to the question of how to approach the topic of this study, it is important to delineate the research object itself. In line with the present volume's theme, the focus of this contribution will lie on pragmatic normative literature..$^{5}$ Like catechisms, glosses and indices, epitomes represent a particular form of generic intertextuality that, as Wolfgang Raible put it, condenses and references a single original work. ${ }^{6}$ These characteristics were mutatis mutandis already part of the first millennium's understanding of the term. For example, a Greco-Latin glossary (Scholica Graecarum glossarum), dating perhaps from the second half of the 9 th century, defines epitomes as excerpts or extracts that are compiled from a more extensive corpus librorum by means of a selection or florilegium and can be described as a succinct ready-to-use presentation. ${ }^{7}$

In this description, which largely correlates with conventional Latin usage in antiquity, ${ }^{8}$ three central characteristics of epitomes become apparent. ${ }^{9}$

lectiones' "; Liebs, "Legis Romanae Visigothorum Epitomen Sangallensem”; Liebs, "Römischrechtliche Glut aus dem 8. Jh. für ein Bischofsgericht in Burgund"; Liebs, "Scintilla de libro legum"; Siems, Handel und Wucher im Spiegel frühmittelalterlicher Rechtsquellen, 191-200; Rambaud-Buhot, "Les divers types d'abrégés du Décret de Gratien"; Rambaud-Buhot, "L'Abbreviatio Decreti d'Omnebene"; Weigand, "Die frühen kanonistischen Schulen und die Dekretabbreviatio Omnebenes”; Weigand, "Die Dekretabbreviatio 'Quoniam egestas' und ihre Glossen”; Weigand, "Die Dekretabbreviatio 'Exceptiones ecclesiasticarum regularum' und ihre Glossen".

5 See on this generally Thomas Duve's contribution (Chapter 1) in this volume.

6 Raible, "Arten des Kommentierens - Arten der Sinnbildung - Arten des Verstehens", 56-61. See also Doering, "Fort- und Neuschreibung autoritativer Texte und Identitätsbildung im Jubiläenbuch sowie in Texten aus Qumran", 72-73.

7 Laistner, "Notes on Greek from the Lectures of a Ninth Century Monastery Teacher", 436: "Epitome: supercisio quae de maiori corpore librorum carptim ac defloratim excerpitur, quae alio nomine brevis expositio ac succincta potest appellari. Quonomine solent Graecorum auctores succinctas et defloratas ex aliis doctoribus expositiunculas appellare". See also Llauró, "Los glossarios de Ripoll", 358 ll. 199-203. Laistner associated this glossary with the teaching activities of Martin of Laon (819-875), whereas Contreni in particular disputed this attribution (ascribing authorship instead to Heiric of Auxerre). See Contreni, "Three Carolingian Texts from Laon", 805-808; Contreni, "The Biblical Glosses of Haimo of Auxerre and John Scottus Eriugena", 427-428; Contreni, The Cathedral School of Laon from 850 to 930, 114, 151 fn. 59 .

8 Thesaurus linguae Latinae, vol. 5.2, col. 692 ll. 20-75 (s.v. epitome). See also Wölfflin, "Epitome".

9 On epitomes and epitomisation in general, see Galdi, L'epitome nella letteratura Latina; Opelt, "Epitome"; Lizzi, "La memoria selettiva"; Horster and Reitz (eds.), Condensing Texts - Condensed Texts; Horster and Reitz, "Handbooks, Epitomes and Florilegia"; Dubischar, "Preserved Knowledge”; Dusil, Schwedler and Schwitter (eds.), Exzerpieren - Kompilieren - Tradieren. 
First, an epitome requires the (pre)existence of a work to serve as its sourcetext. Second, epitomes provide a shorter version of the original that emerges through a process of selection. Third, the expression corpus librorum suggests that the original was a longer single text comprising several books (libri). Epitomes could, thus, be usefully distinguished from florilegia, which consisted of excerpts from several different works. ${ }^{10}$

However, the last of these three characteristics is perhaps more ambiguous than it may at first appear. Already the next sentence in the Scholica Graecarum glossarum, which states that Greek authors refer to short texts drawn from other scholars' works as 'epitomes', could also be understood as applying the term to works comprising excerpts from a number of different source texts. Such texts could be considered epitomes in a broader sense that includes works epitomising several carefully sifted texts (e.g., by a single author), as well as literary hybrids, to the extent that they also contain other forms of presentation.

Moving from the term to the function of epitomes, the Thesaurus linguae Latinae provides the synonyms compendium, breviarium and summarium, ${ }^{11}$ which suggest that epitomisation had two formal objectives: brevity and intelligibility. Achieving these goals required the material to be condensed, and the epitomator could do this either by omitting particular passages but otherwise retaining the original wording, or by paraphrasing the source text's content. On a practical level, the first purpose of epitomes was to spare users the trouble of reading the more extensive original texts, saving them time and bother. Moreover, reducing the length of the text also meant lowering the cost of its reproduction. This, however, could result in the excerpt gradually displacing the original. It is also possible that epitomes were consulted alongside the originals to facilitate working with them, or used to make the source texts known more widely.

This review of epitomes' functions also hints at the insights to be gained for historical research. The first point of interest is the relation between the source text and the epitome. The latter, according to Raible, can be considered a commentary on or interpretation of the original, regardless of whether epitomators paraphrased the text in their own words or excerpted passages. This also raises the question of the temporal relation between the original and the epitome, which can reveal diachronic changes. Second, the content of the epitome itself

\footnotetext{
10 On (Latin) florilegia, see Chadwick, "Florilegium"; Rouse, "Florilegia”; Hamesse, "«Florilège» et «autorité»"; Hess, "Florilegien”; Horster and Reitz, "Handbooks, Epitomes, and Florilegia".

11 See fn. 8.
} 
can provide insights, for example indications of terminological condensation or of the epitome's pragmatic context. A third area of interest lies in exploring the significance of epitomisation for a text's reception and impact as a result of its increased accessibility and dissemination in epitomised form.

This will have to suffice as an introduction to the subject matter. In the following, the phenomenon of epitomisation will be examined more closely in relation to Latin legal texts written between late antiquity and the early modern period. The object of the following brief survey is the technique of epitomisation itself. As can be gathered from the history of legal sources and legal literature, this spanned not only the composition of epitomes of a single original text, that is, epitomes in the narrower sense, but also in the broader sense of epitomes as compilations from multiple texts, as discussed above. Furthermore, it follows from the nature of the subject matter that the questions to be posed here are not limited to the history of sources and literature but also relate to the role that epitomisation played in the development of law, in particular how it affected the adoption, reception and spread of legal knowledge in the so-called premodern era. The answers are likely to come above all from two branches of legal history, which in the following will be considered in more detail: Roman law between late antiquity and the Early Middle Ages and the canon law of the second millennium. These two - historically and substantively rather different - areas of investigation serve to illustrate the complexity of the phenomenon. Of course, the following observations make no claim to comprehensiveness. Rather, they are only a preliminary attempt to describe a phenomenon that remains largely unexplored.

\section{Epitomisation of Roman Law Texts in the First Millennium}

Turning from the genre and the craft of epitomisation to the role that it played in the Roman law of the first millennium, one must, as far as the transmission of texts is concerned, first distinguish between written laws and collections of laws, on the one hand, and legal literature, on the other. Although both types of sources underwent widespread epitomisation, there is a large temporal gap between these processes. ${ }^{12}$ The interval is due to a particularity in the development of Roman law: even though Roman jurisprudence and legal literature reached its apogee in the so-called classical era, which lasted from the second half of the 1st century BC until $235 \mathrm{AD}$, the great, official collections of imperial 
constitutions, the Codex Theodosianus (438) and the Codex Justinianus (529/ $534)$, were not compiled until late antiquity. ${ }^{13}$

Of the works of the classical jurists, however, in most cases only excerpts remain, not least due to late antique "catastrophes of forgetting" (Emil Seckel). ${ }^{14}$ It seems likely that the literary-historical background of this loss of knowledge lay in the early epitomisation of these sources, which not only gave rise to new works of jurisprudence (e.g., Pauli Sententiae, Ulpiani Regulae) based on excerpts of older texts, but also contributed to many early classical works being forgotten. ${ }^{15}$

Was epitomisation, therefore, a symptom of decline? In order to reach a more differentiated assessment of the historical significance of this technique, it seems appropriate to take a closer look at the processes just mentioned. This includes examining specific elements within those broader developments, such as the differences in the continued use of individual late classical works. As post-classical legal writings lacked the extensive casuistry that characterised many classical works, some writings of late classical jurists were still widely consulted and copied even after the $3^{\text {rd century. }}{ }^{16}$

More important than such details, however, is the underlying understanding of the general developments of interest here. People usually consult juridical literature, in order to find out about the current state of the law. When the legal situation changes, older juridical literature becomes obsolete and thus uninteresting for readers - unless, as just discussed, special circumstances provide it with additional relevance. ${ }^{17}$ This simple fact takes us back to the "catastrophes of forgetting". Seckel did not intend the term to denote a general cultural decline in late antiquity. ${ }^{18}$ Instead, he had in mind a phenomenon that

13 However, this does not mean that laws and legislation played only a tangential role in classical Roman law as Fritz Schulz's famous remark about the Romans might seem to suggest: 'The 'law-inspired nation' is not statute-inspired.' See Schulz, Principles of Roman Law, 7. For the historical and ideological background of this viewpoint, see Stagl, "Die Bedeutung von leges publicae im Römischen Recht”, 456-458. See also fn. 24-26.

14 Seckel, Das römische Recht und seine Wissenschaft im Wandel der Jahrhunderte, 11. See Wieacker, Textstufen klassischer Juristen, 151-152.

15 For the development since the 3rd century, see Liebs, "Warum endete gegen Mitte des 3. Jahrhunderts die klassische Rechtsliteratur?"; Liebs, “Jurisprudenz"; Liebs, "Nachklassische römische Rechtsliteratur"; Liebs, "Recht und Rechtsliteratur". On epitomes and epitomisation in classical Roman law see also Schulz, History of Roman Legal Science, 184-186; Schiller, Roman Law, 388-389.

16 Liebs, "Wenn Fachliteratur Gesetz wird", 401-403.

17 Stolleis, "Vom Umgang mit veralteten Büchern, oder: Mit den Toten sprechen”.

18 Wieacker, Römische Rechtsgeschichte, 43 fn. 59. 
can be observed at different points in legal history. ${ }^{19}$ One could also call it the "disappearance of disused law", as Michael Stolleis put it, ${ }^{20}$ or perhaps, by analogy to this, the "disappearance of obsolete legal knowledge".

If 'catastrophes of oblivion' are from a legal-historical point of view both necessary and useful, this also affects our assessment of the epitomes that played a part in them. An antiquarian approach that sees epitomisation mostly as a danger, and only rarely as an aid to the survival of sources, cannot do justice to the phenomenon. The role that epitomisation played in shaping legal knowledge also has to be taken into account. This emerges even more clearly if one turns form the juridical literature to the legislative texts, particularly the compilations of the $5^{\text {th }}$ and 6th centuries that provided the second starting point for processes of epitomisation.

Here, too, context is important, particularly a phenomenon that can perhaps be best described through the metaphor of a forest (silva). ${ }^{21}$ Tertullian, for example, spoke of 'the ancient and rugged forest of laws' (vetus et squalens silva legum). ${ }^{22}$ This image illustrates a problem that made itself felt already towards the end of the Roman Republic. ${ }^{23}$ Owing to the large number of (in part obsolete) laws, someone seeking to understand the current state of the law might easily not be able to see the wood for the trees.

19 According to Seckel, a similar 'catastrophe of forgetting' occurred a thousand years later when the triumph of the Accursian Glossa ordinaria caused the works of the high medieval glossators of Roman law to be forgotten. See Seckel, Das römische Recht und seine Wissenschaft im Wandel der Jahrhunderte, 18 and Kästle-Lamparter, Welt der Kommentare, 178-179. In a lecture given in 1921 ('Das Corpus iuris civilis') Seckel applied the term 'catastrophe of forgetting' also to developments in modern legal history. See "Die Vorträge Emil Seckels in der Berliner Mittwochs-Gesellschaft", ed. Schubert, 371-373 and Spruit, "Visions fugitives", 494-495.

20 Stolleis, "Vom Verschwinden verbrauchten Rechts". See also Guarino, "La rimozione del diritto e l'esperienza romana".

21 On the metaphor of the forest, see Spitz, Die Metaphorik des geistigen Schriftsinns, 130134; Adam, Poetische und kritische Wälder, 57-71; Winter, "A Clearing in the Forest"; Kannengiesser, "Tyconius of Carthage, the Earliest Latin Theoretician of Biblical Hermeneutics", 307-308.

22 Tertullianus, Apologeticum, IV,7, 93: "Nonne et uos cottidie, experimentis inluminantibus tenebras antiquitatis, totam illam ueterem et squalentem siluam legum nouis principalium rescriptorum et edictorum securibus ruspatis et caeditis?" See Nörr, Rechtskritik in der römischen Antike, 58; Nörr, "Zum Traditionalismus der römischen Juristen”, 175.

23 Schwind, Zur Frage der Publikation im Römischen Recht mit Ausblicken in das altgriechische und ptolemäische Rechtsgebiet, 35; Grosso, "Meditazione su Tacito"; Honsell, "Der Gesetzesstil in der römischen Antike", 1664-1665; Mantovani, "Legum multitudo e dritto privato", 713-717. 
Looking at Giovanni Rotondi's (if by now partly outdated) count of Roman laws passed up to the 1st century of the Principate, ${ }^{24}$ the respective number about 800 - appears quite manageable and might seem to suggest that ancient complaints about the 'forest of laws' were just a topos. ${ }^{25}$ However, this impression is based on an anachronistic premise and is therefore misleading. ${ }^{26}$ For an observer who is familiar with the modern flood of legislation, the number of laws that Romans had to cope with might seem like a negligeable quantity. Nonetheless, the criticism of the multitude of laws referred to a problem that was quite real in the eyes of contemporaries and became increasingly troublesome in the later imperial period.

What, then, was more natural than to thin the forest of laws and legal texts? To Tertullian, the axes of imperial rescripts and edicts had been the right tools for the job. As time went by, however, they came to be part of the problem rather than of its solution. Thus, in late antiquity, a different approach was taken. The first step towards thinning the silva legum was to assemble an official collection of laws, such as the Codex Theodosianus and the Codex Justinianus. These contained the laws still of contemporary relevance, though many were included only in the form of extracts. ${ }^{27}$ However, the resulting compilations were expensive to produce and of little use to non-specialists. The second step, then, which took place during the transition from antiquity to the Middle Ages, was the epitomisation of these law books and other legal texts (e.g. the Novellae). ${ }^{28}$

24 Rotondi, Leges publicae populi romani. For the present state of research see Mantovani, "Legum multitudo e dritto privato". In the German translation of the respective article there is an interesting addendum by Mantovani. See Mantovani, Legum multitudo.

25 Schulz, Principles of Roman Law, 9; Santucci, "Legum inopia e diritto privato", 377, 381.

26 Honsell, "Der Gesetzesstil in der römischen Antike", 1664; Cuena Boy, "Exceso de leyes en Roma"; Mantovani, Legum multitudo, 102-107.

27 Leges novellae ad Theodosianum pertinentes, in: Theodosiani libri XVI, vol. 2, eds. Mommsen and Meyer, Nov. Theod. 1,1.3, pp. 3-4: “[... si copia inmensa librorum [...] verum egimus negotium temporis nostri et discussis tenebris conpendio brevitatis lumen legibus dedimus [...] Quamobrem detersa nube voluminum [...] conpendiosam divalium constitutionum scientiam ex divi Constantini temporibus roboramos, [...]". See also Codex Iustinianus, ed. Krüger, 1,17,2,17 (Const. Tanta §17), p. 73 (a. 533): "Mirabile autem aliquid ex his libris emersit, quod multitudo antiqua praesente brevitate paucior invenitur. [...] ut egena quidem antiqua multitudo inveniatur, opulentissima autem brevitas nostra efficiatur". Codex Iustinianus, ed. Krüger, 5,4,24, p. 197 (a. 530): "Sic [...] immensa librorum volumina ad mediocrem modum tandem pervenient".

28 For the Epitome Juliani, which was the main source for knowledge of Justinian's Novels in the Latin West up to the 12 th century, see Iuliani Epitome latina Novellarum Iustiniani, ed. Hänel; Kaiser, Die Epitome Iuliani; Kaiser, "Wandlungen im Verständnis der Epitome Iuliani von der Spätantike bis zur Gegenwart”. 
The epitomisation of the Codex Theodosianus illustrates this process rather well. ${ }^{29}$ After the fall of the Western Roman Empire, an epitome of it was prepared in the Visigothic Kingdom and promulgated and enforced in this form, along with other ancient legal texts (e.g. Epitome Gai and Pauli sententiae), as a law book for the Roman population living under Visigothic rule in 506 AD. ${ }^{30}$ This work, known as the Lex Romana Visigothorum or Breviarium Alarici(anum), represented one of the most important sources for the knowledge of Roman law in the Latin early Middle Ages. It also served as a starting point for Gallo-Roman and Frankish editors to compose 'epitomes of epitomes', which were, however, not official legal texts but works for private use. ${ }^{31}$

One of these 'epitomes of epitomes' is the so-called Epitome Monachi, prepared by an anonymous monk in the 8th century - probably in Burgundy - on the order of his abbot. ${ }^{32}$ Its prologue allows us further insight into the facets of this source type. The author presents his 'little volume' for the reader who does not have the time, or the required knowledge, to study the Roman laws

29 Theodosiani libri XVI, 2 vols., eds. Mommsen and Meyer. See Sirks, The Theodosian Code; Atzeri, Gesta sentus Romani de Theodosiano publicando; Coma Fort, Codex Theodosianus.

30 Lex Romana Visigothorum, ed. Hänel; Legis Romanae Wisigothorum fragmenta. See Nehlsen, "Alarich als Gesetzgeber", 143-203; Lambertini, La codificazione di Alarico II; Lambertini, "Sull'«Epitome Gai» nel «Breviarium»"; Liebs, "Zur Überlieferung und Entstehung des Breviarium Alaricianum"; Martini, "Qualche osservazione a proposito della c.d. Epitome Gai"; Nemo-Pekelman, "How did the authors of the Breviarium Alaricianum work?".

31 Conrat (Cohn), Geschichte der Quellen und Literatur des römischen Rechts im früheren Mittelalter, vol. 1, 222-240; Schwerin, "Die Epitome Guelferbytana zum Breviarium Alaricianum"; Gaudemet, Le Bréviaire d'Alaric et les Epitome; Siems, Handel und Wucher im Spiegel frühmittelalterlicher Rechtsquellen, 194-195; Liebs, Römische Jurisprudenz in Gallien, 249-254; Ganivet, "L'«epitomé de Lyon»"; Trump, "Römisches Recht in Reims".

32 Lex Romana Visigothorum, ed. Hänel, 3 (Epitome Monachi, Prologus): "Quisquis oportuna vacatione minime perfruitur aut capacitate sensus vel prudentia plene imbutus non invenitur, ut iura librorum, id est leges Romanorum plenissime perscrutentur, hoc quod a nobis parvum volumen, quasi de magnis silvis surculum abscissum videtur integre perlegi non aborreat, et videbitur sibi non parvum in huius operis brevitatis inesse compendium, dum sublatis pragmaticis vel longissimis assertionibus et tamen omnes eorum definiciones in hac nostra reperiantur scedula. Volumus etiam omnia capitula legis huius integra admonitione contexere, ut si qua aliqua requirenda sunt, absque mora de hoc Breviario nostro possis in auctorem volum transire. Dignum videtur, ut hoc nostra exemplaria quasi edita subolis suae matris imitetur: [...]". See also Liebs, Römische Jurisprudenz in Gallien, 250. On the work and the passages discussed here see Conrat (Cohn), Geschichte der Quellen und Literatur des römischen Rechts im früheren Mittelalter, vol. 1, 238-239; Gaudemet, Le Bréviaire d'Alaric et les Epitome, 46-47; Siems, Handel und Wucher im Spiegel frühmittelalterlicher Rechtsquellen, 194-195; Liebs, Römische Jurisprudenz in Gallien, 249-254 (see 250-251); Coma Fort, Codex Theodosianus, 331-332. 
collected in the Breviarium Alarici in detail: like a twig (surculus) taken from the large forest of the Breviary, or rather from the Roman laws it contains. ${ }^{33}$ He assures the reader that in his compendium he has omitted all solemn and long-winded passages, but retained all the definiciones contained in them. The work's structure makes clear what exactly he meant by this. Like other epitomisers, the compiler of the Epitome Monachi mostly did not provide the actual text of the imperial constitutions contained in the Breviary nor of the Pauli Sententiae. Instead, he focused on the so-called interpretationes, that is, the excerpts from the older literature on the Theodosian Code preserved in the Breviary. ${ }^{34}$ The author claims that one can easily switch between his own work and the source text. ${ }^{35}$ This is due above all to the relationship between the two works. In the prologue he compares his text (exemplaria) with a newborn offspring (suboles) that emulates its mother.

This simile comes from Pope Gregory the Great's letter of dedication to Leandrus at the beginning of his Moralia in Job. ${ }^{36}$ The pope explains that, as his commentary (expositio) derives from the Bible, it is proper that it takes on the appearance of the mother, that is, the language of Scripture. The author of the Epitome monachi copied most of this sentence, but substituted exemplaria for expositio. ${ }^{37}$ It is possible that he did not want to suggest that his work was also a commentary.

At first sight, the author's emphasis on the close connection between the Breviary and his epitome appears justified. However, there are also features that seem to support the opposite view, such as the substantial cuts/omissions

33 See also [Hieronymus,] Epistula Hieronymi adversus Rufinum presbyterum, ed. Lardet, c. 39, 107 ll. 6-7: "De tanta librorum silua, unum fruticem ac surculum proferre non potes".

34 Lex Romana Visigothorum, ed. Hänel, XxIX-Xxx; Gaudemet, Le Bréviaire d'Alaric et les Epitome, 46; Soliva, "Römisches Recht in Churrätien", 193; Liebs, Römische Jurisprudenz in Gallien, 250. On the interpretationes see Matthews, "Interpreting the Interpretationes on the Breviarium"; Di Cintio, L'«Interpretatio Visigothorum» al «Codex Theodosianus»; Di Cintio, Nuove ricerche sulla «Interpretatio Visigothorum» al «Codex Theodosianus».

35 Adnotationes codicum domini Justiniani, ed. Patetta, XLVI-XlVII; Siems, Handel und Wucher im Spiegel frühmittelalterlicher Rechtsquellen, 194-195; Siems, "Adsimilare", 153.

36 Gregorius Magnus, Moralia in Iob, ed. Adriaen, Epistola ad Leandrum, c. 5, 7 ll. 223-225. On this work see Michel, "Wo das Lamm watet und der Elefant schwimmt"; Kessler, "Gregor der Große und seine Theorie der Exegese".

37 Gregorius Magnus, Moralia in Iob, ed. Adriaen, Epistola ad Leandrum, c. 5, 7 ll. 223225: "Ex qua nimirum quia nostra expositio oritur, dignum profecto est, ut quasi edita soboles speciem suae matris imitetur". See Lex Romana Visigothorum, ed. Hänel, 3 (Epitome Monachi, Prolog): "Dignum videtur, ut hoc nostra exemplaria quasi edita subolis suae matris imitetur" (emphasis added). 
and the above-mentioned remark about the definiciones, which suggests that the author thought them the essential part (as Detlef Liebs translated it), that is, the condensed core substance of the text. ${ }^{38}$ Furthermore, the metaphor of the twig taken from the forest could be read as criticism of the source text. Perhaps the author of the Epitome monachi, which was conceived a priori as a private book of law ("Rechtsbuch", as Liebs put it), deliberately intended to counteract any impression that his Epitome strayed too far from its source. ${ }^{39}$

With this in mind, the simile of mother and child could perhaps gain another layer of meaning, as capturing a relationship of similarity that at the same time includes difference. Following this interpretation, one might ask to what extent the Epitome detached from its 'parent' not only in its existence as a separate text, but also in terms of content. However, we should not expect too much in this regard. The early medieval epitomisers of the Breviarium Alarici generally did not exhibit a deep understanding of their subject matter. ${ }^{40}$ This is also true for the author of the Epitome monachi, though his work is seen as among the better efforts. ${ }^{41} \mathrm{Nev}$ ertheless, the question of epitomes as potentially independent developments of their source text remains of relevance for the genre overall. We will return to the issue of the extent to which epitomes could - as a result of processes of in-depth reflection and carefully thought-through abstraction - represent distinct, even innovative development of their subject matter at the end of this essay. ${ }^{42}$

Turning back from this individual example to the general progression from the Codex Theodosianus to the Breviarium Alaricianum and thence to the latter's epitomes, this process is noteworthy in several respects. First among these is its formal aspect; that is, the dynamic development of the text. Instead of being a process completed in a single step, epitomisation could occur more than once. However, successive iterations did not necessarily reduce the quantity of text, as the transmission of the Codex Justinianus shows. At first, the Code's length was progressively reduced (Epitome codicis), but this condensed Code was subsequently again augmented (Epitome aucta). ${ }^{43}$

\footnotetext{
38 Liebs, Römische Jurisprudenz in Gallien, 251.

39 Liebs, "Das Verbot von Mischehen im germanisch-römischen Recht", 626.

40 Siems, "Adsimilare", 153.

41 Liebs, Römische Jurisprudenz in Gallien, 253.

42 See p. 66.

43 Krüger, Geschichte der Quellen und Literatur des Römischen Rechts, 425-428. Radding and Ciaralli have recently argued against Krüger's theory. See Radding and Ciaralli, The Corpus Iuris Civilis in the Middle Ages, 133-168. However, Radding and Ciaralli's argument depends on a controversial late dating of many works and texts. See Kaiser, "Verkürzt und wiederaufgefüllt?”; Müller, "Review of: Ch. Radding/A. Ciaralli, The Corpus iuris in the Middle Ages".
} 
Beyond such a purely quantitative observation, the increasing textual reduction witnessed in Alaric's Breviary and its epitomes is also interesting for what it reveals about the improved access to legal knowledge. The tendency evident here actually accorded with traditional Roman ideas about good law. The dictum that laws should be short to make them comprehensible for nonexperts appears already in Seneca. ${ }^{44}$ The epitomes' brevity also made sense in terms of the post-Roman legal conditions. In the Latin West, jurists became ever rarer through the 6th and especially the 7th centuries, (almost) completely disappearing after this period. Under these circumstances, in which decreasing literacy and knowledge of Latin presented ever-greater obstacles to comprehension in large parts of Europe, a concise text was certainly advantageous, especially when it came to reaching less proficient readers and thus ensuring at least some adherence to the lex scripta. ${ }^{45}$ In this light the Breviarium Alaricianum and its epitomes appear less as signs of decadence or barbarism than as attempts to preserve the utility of at least some of the knowledge contained in a great codification of late antiquity under changing cultural and legal conditions. ${ }^{46}$

This impression grows even stronger when we turn our attention from epitomes' cognitive-medial aspects to their actual legal content, particularly if one looks at the body of norms contained in the epitomes. The Breviary of Alaric reveals clear differences between Roman law in the early 6th-century Visigothic Kingdom and the two Roman (or, rather, Byzantine) Codes. The differences are not exclusively post-Roman; long before the Visigoths, law had been experienced and practiced very differently in the provinces compared to

44 L. Annaeii Senecae ad Lucilium epistulae morales, vol. 2, ed. Reynolds, ep. 94,38, 373 ll. 8-9: "Legem enim brevem esse oportet, quo facilius ab inperitis teneatur". On the idea of brevitas, which Roman authors held the Law of the Twelve Tables to embody, see Gebhardt, Sermo Iuris, 38-40. Other values, such as simplicitas, prominently demanded by Justinian, were closely connected to the postulate of brevitas, see Schindler, Justinians Haltung zur Klassik, 339-341. Schulz observed a general tendency towards simplification in Roman law between the end of the 3rd century AD and the first third of the 6th century; see Schulz, History of Roman Legal Science, 289-293. This should not be mistaken for a kind of decadence. See Dusil, Schwedler and Schwitter, "Transformationen des Wissens zwischen Spätantike und Frühmittelalter", 9-10.

45 For a discussion on the effectiveness of legal texts in late antiquity and the early Middle Ages, see Schott, "Pactus, Lex und Recht"; Nehlsen, "Aktualität und Effektivität der ältesten germanischen Rechtsaufzeichnungen"; Siems, "Zu Problemen der Bewertung frühmittelalterlicher Rechtstexte".

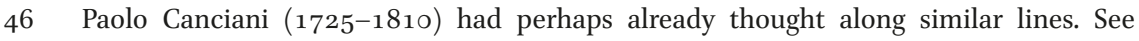
Canciani, Praefatio Collectoris, ed. Canciani, XII-XIII. On Canciani's biography, see Feola, "Canciani, Paolo". 
the image of Roman law transmitted in the Codex Theodosianus and the Codex Justinianus.

Regardless of whether one associates provincial law with the concept of West Roman vulgar law, ${ }^{47}$ it should be clear that how the Theodosian Code and the Breviary of Alaric were epitomised cannot be separated from the redactors' ideas regarding what was (still) applicable law. Indeed, such ideas were a prerequisite to any attempt to clear a path through the undergrowth of texts in the forest of laws. This closes the circle to the classical jurists' texts: as different as the epitomes considered here may be, they all represent efforts to update - by means of selection - and adapt the law to changed legal and extra-legal circumstances. ${ }^{48}$ In other words, the epitomes were an important instrument to restructure both the literary and the legal landscape and thus helped to ensure the survival of the lex scripta. In this sense, epitomisation made it possible to continue working with at least a basic stock of Roman legal texts and to transmit the knowledge they contained during a time of profound institutional change.

This observation brings us back to the question of how to evaluate the process of epitomisation in the first millennium from the perspective of Roman law. As far as the quality of many late antique and early medieval epitomes is concerned, the traditional assessment cannot be entirely dismissed. Passages that represent a useful abridgment of the original text are interspersed with others that clearly betray how little the epitomator understood it. Nonetheless, the traditional wholesale condemnation remains deficient in many ways. It is ahistorical in its application of standards stemming from classical antiquity, its assumed causality is erroneous, and its perception is selective.

\section{Epitomes in the Ecclesiastical Legal Culture of the Second Millennium}

Moving on from the Roman law of late antiquity and the early Middle Ages, it is clear that epitomised texts played little role in the transmission of contemporary non-Roman secular law. ${ }^{49}$ In contrast, they permeated the canon

47 Kaiser, "Vulgarrecht"; Liebs, "Roman Vulgar Law in Late Antiquity"; Sánchez-Moreno Ellart, "Law, 'vulgar'”.

48 Weiß, "Schwund und Konservierung im römischen juristischen Schrifttum"; Schiller, Roman Law, 384; Gaudemet, Le Bréviaire d'Alaric et les Epitome, 42.

49 On Lombard law, see Moschetti, Primordi esegetici sulla legislazione longobarda nel sec. IX a Verona, 151-167; Angelini, "Annotazioni sull'epitome greca dell'Editto di Rotari”. For 
law of the first millennium. ${ }^{50}$ Similar interests and goals explain the existence of epitomes of canon law as in the case of their Roman law counterparts. ${ }^{51}$ Epitomisation in the sphere of Church law focused particularly on the acts of Church councils (e.g., the Breviarium Hipponense) and, of course, on the collections of canon law (e.g., the Breviatio canonum of Fulgentius Ferrandus and the Epitome Hispana). ${ }^{52}$ Even though the corpus of canon law texts grew and that of Roman law shrunk over the course of the second half of the first millennium, those composing epitomes of canon law faced relatively few problems compared to those assembling corresponding Roman law compendia at that time. From the middle of the 11th century onwards, however, the Gregorian Reform and the Investiture Controversy led to a rapid rise in the number of canon law collections. Before examining the resulting developments in more depth, it is necessary to clarify some fundamental differences between the phenomena discussed so far and the developments during the second millennium that will be considered below.

The codifications of the $5^{\text {th }}$ and 6th centuries were an attempt to create a comprehensive representation of an unwieldy legal architecture, which until then had existed mainly in the minds of jurists, under the supervision of the state. Theodosius' and Justinian's Codes were intended to be the central source of information for those seeking to understand the current state of the law. The general decline in statehood and literacy in the Latin West, however, meant that these texts had little applicability in the barbarian successor states and mostly fell into oblivion. This development is easy to understand if one considers the availability of knowledge of Roman law in the second half of the first millennium. Early medieval scholars only rarely had access to collections of specialist legal literature, and even less to the legal training needed to find one's way through the large Roman law compilations of late antiquity.

the isolated epitome De legibus divinis et humanis drawn from Isidore's Etymologiae see Tardif, "Un abrégé juridique des Étymologies d'Isidore de Séville".

50 For examples of epitomised canon law collections before Gratian's Decree, i.e. before the second third of the 12th century, see Kéry, Canonical Collections of the Early Middle Ages (ca. 40o-1140), 11, 21-24, 57-6o, 81-82, 147-148, 180-181, 187, 206, 241, 252, $264,287$.

51 In the prologue to the Collectio Hibernensis, a systematic collection of canon law from the first half of the 8th century, the compiler states his motivation succinctly as wanting to trim the ingens silva scriptorum down to a short, complete and harmonious depiction. See The Hibernensis, ed. Flechner, 1.

52 Munier, "La tradition manuscrite de l'Abrégé d'Hippone et le canon des Écritures des églises africaines"; Landau, "Die Breviatio canonum des Ferrandus in der Geschichte des kanonischen Rechts"; Kéry, Canonical Collections of the Early Middle Ages (ca. 400-1140), 23-24, 57-6o; Sedano, "Breviarium". 
The situation in the early second millennium, with the so-called 12thcentury Renaissance and the attendant rebirth of jurisprudence and legal literature, was strikingly different. ${ }^{53}$ In Bologna, Irnerius ( $†$ around 1130) and his followers studied, taught, and commented on the body of Justinianic texts (the Institutes, the Digest, the Code of Justinian and the Novels), later to become known as the Corpus Juris Civilis. Not long thereafter, Gratian ( $\dagger$ probably before 1150) founded a school of canon law, also in Bologna. This rise in the academic study of civil and canon law went hand in hand with a broader trend of flourishing scholarship and a growing library of texts. Consequently, new forms both of intensive and selective reading, textbooks such as Peter Lombard's ( †1160) Sentences, and numerous aids for readers appeared. ${ }^{54}$ Innovations such as these were closely related to the new academic culture of early scholasticism, which was not only materialiter marked by the increasing currency of text-based knowledge, but also characterised intellectually by the spirit of literacy and textuality. ${ }^{55}$

These contextual details cast a new light on the phenomena under discussion. Most of the epitomes of Roman law composed at the transition of late antiquity to the early Middle Ages were considerably younger than the source texts. Due to changing cultural and legal conditions, they came to supplant the original text rather than to be used in conjunction with them. They consolidated those aspects of legal knowledge that were still relevant and in this way kept them available. By contrast, many canonistic and theological epitomes of the later Middle Ages were produced not long after their source texts. Their special significance lay in the fact that they provided readers with a point of entry to the more comprehensive originals or served to make their contents better known. Epitomisation in the later Middle Ages was therefore not concerned

53 Otte, "Die Rechtswissenschaft"; Kuttner, "The Revival of Jurisprudence".

54 Petrus Lombardus, Sententiae in IV libris distinctae, vol. 1, Prologus n. 5, 4 ll. 23-26: "[...] brevi volumine complicans Patrum sententias, appositis eorum testimoniis, ut non sit necesse quaerenti librorum numerositatem evolvere, cui brevitas collecta quod quaeritur offert sine labore". See Grabmann, Die Geschichte der scholastischen Methode, vol. 2, 8485; Rouse and Rouse, "La naissance des index", 97. On this development in general, see Parkes, "The Influence of the Concepts of Ordinatio and Compilatio on the Development of the Book"; Rouse and Rouse, "Statim invenire"; Hathaway, "Compilatio"; Illich, In the Vineyard of the Text; Hamesse, "A propos de quelques techniques d'interprétation et de compilation des textes". On the learned laws see Dolezalek and Weigand, "Das Geheimnis der roten Zeichen”; Montorzi, "Processi di 'standardizzazione' testuale: margaritae, gemmae, tabulae”; Meyer, "Ordnung durch Ordnen”, 338-339; L'Engle, "The Pro-Active Reader".

Schönberger, Was ist Scholastik?, 83-86. 
with the preservation of legal knowledge. On the contrary, its condensation served its expansion and diffusion.

This was particularly evident in the field of canon law. ${ }^{56}$ Since the mid-12th century it had developed as an academic discipline with its own literature and science based on the interpretation of the Decretum Gratiani, completed around 1145 - a private collection of canon law compiled by the abovementioned monk Gratian. ${ }^{57}$ Epitomising adaptations of the Decree began to appear afterwards: the so-called 'abbreviationes' (e.g., by Omnibonus (Omnebene)), ${ }^{58}$ which largely preserved the original order of the Decretum's sources, and the so-called 'transformationes' (e.g., of Laborans), ${ }^{59}$ which not only considerably reduced Gratian's text, but also rearranged the sources included. ${ }^{60}$

Three 'abbreviationes' of the Decretum Gratiani composed around the turn of the 13th century reveal the quantitative dimension of canonistic epitomisation. ${ }^{61}$ It is immediately apparent that all three works excised over $9 \circ \%$ of the content of the Decretum, though the intensitiy of the epitomisation varied for different parts of Gratian's work. However, these 'abbreviationes' also demonstrate that the epitomators did not simply follow a general scheme, but instead clearly based their decisions on what to include on careful consideration of the text's contents. Finally, the 'abbreviationes' of Gratian's Decree are also interesting in terms of their form and style. Some of them were composed in verse rather than prose. ${ }^{62}$ As strange as that may seem today, rendering an

$5^{6}$ For Roman law epitomes in the 12th and 13th centuries, see Weimar, "Die legistische Literatur der Glossatorenzeit", 251-258.

57 Winroth, The Making of Gratian's Decretum; Winroth, "Where Gratian Slept"; Landau, "Gratian and the Decretum Gratiani"; Wei, "The Later Development of Gratian's Decretum"; Dusil, "The Decretum of Gratian". On the resemblance of the Decretum Gratiani to a florilegium, see Waelkens, "Le Décret de Gratien", 258-259.

$5^{8}$ On Omnibus (Omnebene), see fn. 4 above. See also Vetulani and Uruszczak, "L'œuvre d'Omnebene dans le MS 602 de la Bibliothèque municipale de Cambrai".

59 Martin, Die 'Compilatio Decretorum' des Kardinals Laborans.

6o Kuttner, Repertorium der Kanonistik (1140-1234), 257-271; Ullmann, "The Paleae in Cambridge Manuscripts of the Decretum", 175 fn. 26; Zapp, "Abbreviationes"; Beyer, Lokale Abbreviationen des Decretum Gratiani; Fransen, "Les abrégés de collections canoniques", 160; Brasington, "The Abbreviatio 'Exceptiones evangelicarum"; Kimmel, "Abbreviatio des Decretum Gratiani mit Ergänzungen"; Roumy, "Un abrégé inconnu du Décret de Gratien"; Landau, "Gratian and the Decretum Gratiani", 46-47; Pennington and Müller, "The Decretists", 123-125; Larson, "An Abbreviatio of the First Recension of Gratian's Decretum in Munich?"; León, "Abbreviatio".

61 Beyer, Lokale Abbreviationen des Decretum Gratiani.

62 Worstbrock, "Libri pauperum", 46-47. See also Schulte, "Zur Geschichte der Literatur über das Dekret Gratians", 26-29; Schmidt-Wiegand, "Rechtsverse”; Black, "Teaching the Mnemonic Bishop in the Medieval Canon Law Classroom". 
'abbreviatio' in verse form was clearly intended to aid its memorisation. This raises questions about the use of mnemonic techniques by canon lawyers more generally, which however lies outside the scope of the article. ${ }^{63}$

In contrast to the many 'abbreviationes' that greatly contributed to the spread of Gratian's Decree, ${ }^{64}$ the 'transformationes' generated little interest and remained the exception. Both literary genres can be called epitomes of canon law collections in the narrow sense of the term discussed above, because they aim to represent a single original text in its entirety, whether verbatim or in paraphrase. Other canonistic genres emerging at that time (e.g., 'casus' and 'notabilia'), on the other hand, were epitomes of canon law in the broader sense, because they excerpted only from parts of a text, drew on several source texts or contained elements of other canonistic genres, too. ${ }^{65}$

The developments described above essentially took place during the age of the so-called decretists, during which the Decretum Gratiani was the focus of interest in canon law (until ca. 119o). However, the landscape changed in the subsequent period of the so-called decretalists. During this period the focus of canonistic scholarship lay on the production of decretal collections and commentaries on them. This is particularly true for the time after the promulgation of the Liber Extra (1234). While 'abbreviationes' of the new papal decretal collections were produced, they were relatively few in number. ${ }^{66}$ The focus of epitomising activity had started to shift. Most canonistic works of the 12th century were (compared to the Decretum Gratiani) not that extensive and therefore did not particularly require the production of abridged versions. ${ }^{67} \mathrm{In}$

63 On mnemonic techniques, see Mazzacane, "El jurista y la memoria"; Meyer, "Spuren im Wald der Erinnerung”; Stolleis, "Corpus Iuris Civilis par cœur”; Rivers, "Remembering Canon and Civil Law around 1400"; Rivers, "Learning and Remembering Canon Law in the Fifteenth Century". For the mnemonic function of the scholastic page layout see Frońska, "Memory and the Making of Images"; Frońska, "Turning the Pages of Legal Manuscripts: Reading and Remembering the Law"; Frońska, "The Memory of Roman Law in an Illuminated Manuscript of Justinian's Digest". See also fn. 99-115 below.

64 Landau, "Gratian", col. 533.

65 Kuttner, Repertorium der Kanonistik (1 140-1234), 228-239; Figueira, "Ricardus de Mores and his Casus decretalium: the Birth of a Canonistic Genre", 174-175. On the decretalistic genres in question, see Kuttner, Repertorium der Kanonistik (1140-1234), 397-415. On the 'casus', see also Bertram, "Casus legum sive suffragia monachorum".

66 Schulte, Die Geschichte der Quellen und Literatur des canonischen Rechts, vol. 2, 66, 492495; Van Hove, Prolegomena, 484-486; Ourliac and Gilles, La période post-classique (1378-1500), vol. 1, 121-123; Pennington, "Decretal Collections", 304. On the 'abbreviationes' of decretal collections before 1234, see Kuttner, Repertorium der Kanonistik (1140-1234), 434-437.

67 However, epitomes of decretist works can also be found, for example, in the context of Simon of Bisignano's Summa, written between 1177 and 1179. See Summa in Decretum 
the course of the 13th century, however, the decretalists produced ever more extensive works. It comes as no surprise, therefore, that epitomes of the most diverse genres of canon law literature gained in significance. ${ }^{68}$ Moreover, the increasingly popular genre of canon law repertories also included epitomising elements. ${ }^{69}$

Irrespective of at what time or in which field of high and late medieval canon law or civil law epitomes were composed, one of the main underlying reasons for their production was economic. Many scholars could not afford the extensive and therefore expensive Libri legales and the attendant scholarly literature, making them reliant on excerpts of all kinds. ${ }^{70}$ That authors of epitomes took note of this concern is apparent even in the titles and opening lines of several works, such as the civil law Liber pauperum of Vacarius (c. 1115/ 20 - c. 1200) and Quoniam egestas, an 'abbreviatio' of the Decretum. ${ }^{71}$

Sometimes other factors were added to the need for affordability, which led to the development of a particular form of epitomising canonistic literature distinct from those of the works discussed above. A passage drawn from the prologue of the Casus ad summam Henrici ('Labia sacerdotis') from about 1290 elucidates this particular development. ${ }^{72}$ In it, the author, probably a

Simonis Bisinianensis, ed. Aimone Braida; Aimone, "Alcune note sulla Abbreviatio Dunelmensis della Summa Simonis Bisinianensis".

68 Schulte, Die Geschichte der Quellen und Literatur des canonischen Rechts, vol. 2, 483. Larson, "Géneros literarios canónicos", 191-192. For the role of epitomes in scholastic theology and philosophy, see Michelitsch, Kommentatoren zur Summa Theologiae des hl. Thomas von Aquin, 171-176; Grabmann, Methoden und Hilfsmittel des Aristotelesstudiums im Mittelalter, 54-104; Grabmann, "Hilfsmittel des Thomasstudiums aus alter Zeit", 425-452.

69 Schulte, Die Geschichte der Quellen und Literatur des canonischen Rechts, vol. 2, 485-489; Van Hove, Prolegomena, 486-488; Ourliac and Gilles, La période post-classique (1378150o), vol. 1, 125-126. See also Horn, "Die legistische Literatur der Kommentatoren und der Ausbreitung des gelehrten Rechts", 349-354.

70 Worstbrock, "Libri pauperum", 43-46; Hamesse, "A propos de quelques techniques d'interprétation et de compilation des textes", 23-24.

71 On the Liber pauperum, see The Liber Pauperum of Vacarius, ed. Zulueta; Taliadoros, Law and Theology in Twelfth-Century England. On Quoniam egestas, see fn. 4 above as well as León, "La abreviación 'quoniam egestas' del Decreto de Graciano".

72 Kurtscheid, "De studio juris canonici in Ordine Fratrum Minorum saeculo XIII", $168-$ 169: "Cum summam henrici fratribus legerem et quosdam casus lectioni insererem, quos textus eiusdem summule non habebat, fratres multimodis precibus ac importunis instanciis me rogarunt, ut eosdem casus verbis brevibus et simplicibus annotarem, quatenus fratres simplices ad planiciem eorundem casuum expediendis penitencium perplexitatibus recurrerent, qui non possent se ac confitentes sibi in latebrosa silva iuris canonici ad liquidum expedire ... Igitur de textu decretalium et decretorum et de summis ac apparatibus magistrorum famosorum ac valde nominatorum in iure canonico 
Franciscan working in the German-speaking lands, describes inter alia the origins of his work. Probably in the course of a lecture on Henry of Merseburg's Summa of canon law, ${ }^{73}$ he also presented those contents (casus) of decretals that were not included in Henry's work. Afterwards his fellow friars asked him to "explain the relevant casus in short and simple (written) words, so that the simple brothers who can lead neither themselves nor those who confess to them, through the dark forest of canon law and into certainty, can get to the bottom of the respective casus and thus be able to alleviate their penitents' difficulties".74 The author proceeded to compose his casus with explanations based on excerpts from the decretals, from Gratian's Decree and the summae and gloss apparatuses of renowned scholars of canon law.

This passage from the prologue is interesting for several reasons, first among which is the reference to the 'dark forest of canon law'. As this notion appeared already in the 12th century, it may at first glance not seem particularly worthy of note..$^{75}$ For the author of the Casus, however, the overgrown silva was problematic for a different reason that it had been for earlier canonists or Roman lawyers. He was not concerned by the complexity of the ecclesiastical legal order per se ${ }^{76}$ but about one particular aspect of it, as the remark about the 'simple brothers' makes clear. These fellow friars asking him for an accessible work were not simple in that they were uneducated or simpletons; ${ }^{77}$ rather, the author was more likely referring to members of the audience of his lectures who

cum magnis laboribus et crebris vigiliis casus quosdam prout potui collegi, et certis titulis prout eorum materie magis videbatur congruere annotavi". See also Kurtscheid, "De studio juris canonici in Ordine Fratrum Minorum saeculo XIII", 169-172 (on the work); Schulte, Die Geschichte der Quellen und Literatur des canonischen Rechts, vol. 2, 535536; Ertl, Religion und Disziplin, 410-411 (text); Goering, "The Internal Forum and the Literature of Penance and Confession", 424. On the casus as a genre, see fn. 65 above.

On Henry of Merseburg and his Summa, see Müller, "Heinrich v. Merseburg”; Dannenberg, "Der lange Arm des Gesetzes", 344-347.

74 For a somewhat divergent German translation, see Ertl, Religion und Disziplin, 281.

75 As expressed, for example, by the canonist Stephen of Tournai (1128-1203). See Étienne de Tournai, Lettres, ed. Desilve, Ep. 274 (a. 1182), 345 (inextricabilis silva decretalium epistolarum). The same metaphor appears in the work of Peter of Blois (c. 1135-1211) in reference to the Digest. See Petrus Blesensis, Epistolae, Ep. 140, col. 416C (quam dumosa silva, quam immeabile pelagus sit Pandecta). On the antique patristic origins, see Alanus de Insulis, Liber in distinctionibus dictionum theologicalium, col. 944C. See also Meyer, "Ordnung durch Ordnen", 350-353.

76 On this general problem of canon law before the Code of 1917, see Stickler, Historia iuris canonici latini, 371-376.

77 Kuttner, "On the Place of Canon Law in a General History of Roman Law during the Middle Ages", 55. On the normatively charged diction, see Wesjohann, "Simplicitas als franziskanisches Ideal und der Prozeß der Institutionalisierung des Minoritenordens". 
were interested in accessible knowledge regarding difficult and extensive legal texts. However, their interest was neither scholarly nor academic. The fratres were motivated in their search for instruction by their work as confessors, for which they required practical knowledge of canon law that they petioned the author of the Casus ad summam Henrici to provide.

Such a concern was in keeping with the developments at the time. From the second half of the 13th century onwards, we find an increasing number of canonistic epitomes directed at readers who were not specialists and might even have stood outside the world of learning. ${ }^{78}$ Such readers would principally include members of the secular clergy and mendicants who required basic practical knowledge of canon law in order to exercise their confessional jurisdiction, i.e. in the so-called forum internum..$^{79}$ The existence of such a readership, sometimes referred to as simplices, ${ }^{80}$ indicates the importance of a heterogeneous and underexplored group of writings, which Stintzing has called the 'popular' literature of Roman and canon law and which played a major role in the dissemination of ius commune. ${ }^{81}$

Another type of text that belongs to the category of pragmatic writings, are the manuals for confessors, or Summae confessorum, that often consisted of excerpts from works of canon law and theology. ${ }^{82}$ These were especially popular among theologians looking for a brief summary of canon law. ${ }^{83}$ One

78 Schulte, Die Geschichte der Quellen und Literatur des canonischen Rechts, vol. 2, 478; Bergfeld, "Katholische Moraltheologie und Naturrechtslehre", 1009. See also MichaudQuantin, "Les méthodes de la pastorale du XIII" au XVe siècle"; Furtenbach and Kalb, "Die Rechtsliteratur in volkssprachiger Überlieferung in Österreich".

79 On the forum internum, see Kéry, "Forum externum, Forum internum"; Arrieta, "Fuero interno".

8o On the manifold connotations of the term simplices, see Bertram, "Casus legum sive suffragia monachorum", 328-329 (51); Brundage, "E pluribus unum”, 25. See also fn. 77 above.

81 Stintzing, Geschichte der populären Literatur des römisch-kanonischen Rechts in Deutschland am Ende des fünfzehnten und im Anfang des sechszehnten Jahrhunderts; Stintzing, Geschichte der deutschen Rechtswissenschaft, vol. 1, 77-85. See also SchmidtWiegand, "Populärjurisprudenz zwischen Artesliteratur und Richterlichem Clagspiegel". For a critique of Stintzing and his use of the term 'popular literature', see Trusen, Anfänge des gelehrten Rechts in Deutschland, 127-134; Becker, "Das kanonische Recht im vorreformatorischen Zeitalter", 16-18. See also the contrasting view in Wejwoda, Spätmittelalterliche Jurisprudenz zwischen Rechtspraxis, Universität und kirchlicher Karriere, 346-347. For a reconsideration of these and related works, see Thomas Duve in this volume (Chapter 1 , section $5^{-6}$ ).

82 On this genre, see Boyle, "Summae confessorum"; Schmoeckel, "Beichtstuhljurisprudenz"; Goering, "The Internal Forum and the Literature of Penance and Confession", 418-427.

83 Melchor Cano (1509-156o) provides a 16th-century example. See Canus, De locis theologicis libri duodecim, lib. viII, cap. 6, 283. It applies equally to Martin Luther who first studied the Summa Angelica and then, on 10 December 1520, burned it along with 
such manual, the Summa Angelica, which Angelo Carletti (1410-1495) composed around 1462, accumulated so many additiones - above all by Giacomo Ungarelli ( $\uparrow 1517)$ - in (the course of) its 16th-century editions that the result practically constituted a gloss. ${ }^{84}$ The connection between excerpting, or rather epitomisation, and glossing, which can be traced back to the 'abbreviationes' of the Decretum Gratiani and continued in later centuries, is remarkable for two reasons. First, it testifies to the intellectual potential contained in the process of epitomisation. Epitomators did not merely abridge texts, they also condensed their contents. Second, the resulting greater conceptual depth was often accompanied by the addition of further texts, ${ }^{85}$ which reveal epitomes' remarkable potential for expansion.

The above observations about the Casus ad summam Henrici, the confessors' manuals and the dynamics of how these texts developed, already provide some clues regarding their raison d'être. Their purpose was to furnish clerics involved in pastoral work with the basics of canon law (which, if necessary, could be extended later) as well as key issues of moral theology. Some of them also provided basic insights into secular, more precisely Roman, law. The legal historical significance of such condensed and mobilised knowledge was most visible at some remove from the great centres of canon-law scholarship. In such areas, the literature for the forum internum made an important contribution to the spread of learned law, as was the case, for instance, in the late medieval Regnum Teutonicum. ${ }^{86}$ The detailed workings of this process need not detain us here. Far more interesting is the role played by the literature based on epitomisation in spreading knowledge about canon law and the resulting changes in regional legal cultures. This is true not only of late medieval and

the bull declaring his excommunication and parts of the Corpus Juris Canonici. See D. Martin Luthers Werke. Kritische Gesamtausgabe, vol. 5: Tischreden aus den Jahren 1544-1544, 680, n. 6471: Ego Martinus Lutherus volens cognoscere iura ecclesiastica legi Summam Angelicam. See also Boehmer, "Luther und der 10. Dezember 1520" and Ohst, Pflichtbeichte, 223-224, 295. On the Summa Angelica see fn. 84.

84 On the additions and Giacomo Ungarelli, see Schmitt, "Jacques Ungarelli"; Buzzi, "La tradizione teologica milanese tra Cinque e Seicento", 144. The author did not have access to the following monograph: Dell'Olmo and Scuccimarra, Il beato Angelo Carletti da Chiavasso. On the Summa Angelica in general, see Viora, "La Summa Angelica"; Montanos Ferrín, "A modo de consulta sobre la literatur jurídica del ius commune, III".

85 Ocker, "The Fusion of Papal Ideology and Biblical Exegesis in the Fourteenth Century", 137-139; Ocker, Johannes Klenkok, 22 fn. 21.

86 Trusen, "Forum internum und gelehrtes Recht im Spätmittelalter"; Trusen, "Zur Bedeutung des geistlichen Forum internum und externum für die spätmittelalterliche Gesellschaft". On the legistic literature, see Horn, "Die legistische Literatur der Kommentatoren und der Ausbreitung des gelehrten Rechts", 284-285. 
early modern Europe, but also of areas outside Europe, as evidenced by the pragmatic normative literature of early modern Ibero-America. ${ }^{87}$

After this brief digression into the pragmatic side of epitomisation the final section focusses on the role of this technique and the related literary genres in the (early) modern period. First of all, we should note that both continued to be present in post-medieval Catholic canon law. However, compared to the age of classical canon law in the 12th to 14th centuries, the emphasis shifted once more. There are few early modern 'abbreviationes' of the great legal collections (Decretum Gratiani, Liber Extra, Liber Sextus, Constitutiones Clementinae) that from about 1500 onwards were gathered together in the Corpus Juris Canonici. ${ }^{88}$ Instead, one encounters Summae conciliorum (like that of Bartolomé Carranza y Miranda), ${ }^{89}$ excerpts from the great bullaria and occasionally epitomes of monastic rules..$^{90}$ Moreover, it is striking that quite a number of works whose titles suggest them to be epitomes of legal sources are little more than indices or repertories. ${ }^{91}$

To the literature of canon law, however, epitomisation continued to be very important. In the field of canon law works of greater scope were subject to epitomisation, if perhaps less frequently than in contemporary Catholic moral theology. ${ }^{92}$ Some texts were condensed into such compendia by the authors

87 In the current volume, Manuela Bragagnolo's contribution (Chapter 6, in particular section 5 ) is of particular interest in reference to epitomisation.

88 See, for example, Mesnartius, Legum pontificiarum Gregorii noui, seu Decretalium pentateuchus; Becker, Compendium juris decretalium; Becker, Decretum Gratiani abbreviatum [...]. As far as the latter two books are concerned, it should be noted that Becker $(1724-1790)$ was more interested in the history of canon law than in its application. See Schulte, Die Geschichte der Quellen und Literatur des canonischen Rechts, vol. 3.1, 232233. See also Holthöfer, "Die Literatur zum gemeinen und partikularen Recht in Italien, Frankreich, Spanien und Portugal", 135, 209-210. The work of Giovanni Battista Scorza (1553-1627) offers much more than a mere epitome. See Scortia, In selectas summorum pontificum constitutiones epitome.

89 Duval, "La Summa Conciliorum de Barthélemy Carranza".

90 On the Summae conciliorum, see Sieben, Die katholische Konzilsidee von der Reformation bis zur Aufklärung, 235-239 (see also 472-476); Sieben, Kleines Lexikon zur Geschichte der Konzilsidee, 179-180 (s.v. Summen). On excerpts and repertories of the bullaries, see von Schulte, Die Geschichte der Quellen und Literatur des canonischen Rechts, vol. 3.1, 68 fn. 8. Giovannni Domenico Mansi's epitome of the bullary of Benedict XIV is especially noteworthy. See Mansi, Epitome doctrinae moralis. On the constitutions of the Jesuits, see Ruiz Jurado, "De las Constituciones S.J. al Epítome".

91 For example, Maranta, Medulla Decreti; Rives, Epitome canonum conciliorum; Brancatus, Epitome canonum omnium [...]; Schram, Epitome canonum ecclesiasticorum ex conciliis Germaniae. See Naz, "Tabula alphabetica juris".

92 Already Schulte was able to identify four epitomes of Tomás Sánchez's (1550-1610) De matrimonio, which was repeatedly reissued. See Schulte, Die Geschichte der Quellen und 
themselves. ${ }^{93}$ In still other literary genres, like the paratitla of canon law, legal sources and the related literature were epitomised together. ${ }^{94}$

Noting that epitomisation was practised in many forms in early modern canon law is not to imply, however, that the technique and the genres it produced were universally approved. Particularly their use in academic instruction at times attracted criticism. For example, the 1598 statutes of the University of Paris prohibited the use of epitomes for teaching purposes in the Faculty of Canon Law, probably to ensure that students read the legal texts themselves (in their entirety) instead of relying on excerpts. ${ }^{95}$ The introductory didactic texts of renowned scholars of canon law (e.g. François Florent and Jean Doujat) and theologians (e.g. Martin Gerbert) also warned against the use of epitomes. ${ }^{96}$

It is no coincidence that, over the course of the 18th century, such criticisms were expressed ever more rarely before disappearing completely. Epitomisation presupposes of large (numbers of) texts, and the quantity of canonistic texts being produced shrank drastically over the course of the 18th century. This is also reflected in the most common sizes of books. While folios and quartos dominated at the beginning of the century, its end belonged to octavos and duodecimos. Far-reaching institutional and methodological changes were responsible for the shift. Many provisions of canon law were dead letters long before (and certainly after) the fall of the ancien régime, making any in-depth

Literatur des canonischen Rechts, vol. 3.1, 737 fn. 2. On Sánchez, see Carrodeguas, La sacramentalidad del matrimonio; Alfieri, Nella camera degli sposi. On moral theology, see Grabmann, "Das Weiterwirken des moraltheologischen Schrifttums des hl. Thomas von Aquin im Mittelalter"; Hurtubise, La casuistique dans tous ses états, 35-37.

93 For example, Vitus Pichler (1670-1736) first composed his more extensive Candidatus jurisprudentiae sacrae from 1716 to 1721 and then his much shorter Candidatus abbreviatus, which he first published in 1731. Both works saw several editions. See Pichler, Candidatus jurisprudentiae sacrae, 5 vols.; Pichler, Candidatus abbreviatus jurisprudentiae sacrae, 2 vols. On Pichler, see Fritsch, Religiöse Toleranz im Zeitalter der Aufklärung, $236-247$.

94 On this genre, see Scherer, Handbuch des Kirchenrechtes, vol. 1, 123; Van Hove, Prolegomena, 544-545. For paratitla in Antoine de Mouchy's edition of the Decretum Gratiani (first printing: 1547), see Landau, "Gratian and the Decretum Gratiani", 5 o.

95 Reformation de l'Université de Paris, Appendix ad reformationem Facultatis iuris Canonici, art. XIV. See Périès, La Faculté de droit dans l'ancienne Université de Paris (1 16o-1793), $209 \mathrm{fn}$. 3. This regulation also appears in the 1662 statutes of Reims University (Statuta facultatis juris academiae Remensis, art. 17), but directed at the Faculty of Law. See Archives legislatives de la ville de Reims, vol. 2.1, ed. Varin, $75^{8}$.

96 Florens, Oratio in aperiendis scholis iuris habita, 63; Doujat, Praenotionum canonicarum libri quinque, lib. IV, cap. 21, n. 11, 518; Gerbert, Apparatus ad eruditionem theologicam, 118-120. 
engagement with the traditional - once intensively discussed - body of norms unnecessary. In addition, further, new methodological approaches introduced rationalistic, deductive modes of representation that replaced the scholastic methods of textual work. ${ }^{97}$

Thus, the traditional canon law epitomes that had condensed lengthy learned discussions to their essentials, therefore lost their raison d'être. Furthermore, new ideas valorising authorship and originality made the epitomisation of others' works seem increasingly questionable. However, we find authors writing on canon law condensing their own extensive handbooks into shorter textsbooks also in the 19th and 2oth centuries. Moreover, until the end of the 2oth century scholarship on canon law and moral theology also produced works that in their titles labelled themselves 'epitomes'. ${ }^{98}$ Generally, though, such works would perhaps be better described as summaries of canon law or moral theology based on selected materials. The era of classical epitomes ended once and for all with the Latin Catholic Church's first codification of canon law, the Codex Iuris Canonici of 1917, which almost removed the need to refer back to the Corpus Juris Canonici or, indeed, to older canonistic literature. The world of the premodern textual culture of canon law in which epitomisation was firmly anchored was no more.

\section{Diagrams (tabulae) in (Early) Modern Canon Law and Moral Theology}

Apart from works composed in running prose another aspect in which the epitomising tradition continued into the modern era remains to be discussed. From 1785 to 1789 Giovanni Devoti (1744-1822) published a textbook on the institutions of canon law in four volumes that, as one of the few works on canon law produced during the late ancien régime, went through a number of editions in the 19th century. ${ }^{99}$ In 1835 , more than a decade after Devoti's death, Camillo Tarquini (1810-1874), who himself went on to become a noteworthy canonist, completed his doctorate in canon law in Rome with an unusual dissertation

97 Meyer, "Kanonistik im Zeitalter von Absolutismus und Aufklärung".

98 For example, Vermeersch and Creusen, Epitome iuris canonici, 3 vols.; Serraino, Epitome juris canonici. On moral theology, see Telch, Epitome theologiae moralis; Ferreres, Epitome theologiae moralis. Judging from the titles, only Noldin's adaptation of Telch's textbook can be classified as a real epitome.

99 Devoti, Institutionum canonicarum libri $I V, 4$ vols. See Lauro, "Devoti, Giovanni"; Fantappiè, Chiesa romana e modernità giuridica, vol. 1, 121-123. 
which he published anonymously in the same year. ${ }^{100}$ Forgoing running prose, he had converted Devoti's textbook into tabular diagrams (tabulae) instead (see figure 2.1).

Such interest in graphical modes of representation was not exactly new. From the 11th century onwards, we find so-called 'schematic distinctions' in manuscripts of civil as well as canon law. In these, concepts and rules included in legal provisions or auctoritates were illustrated, e.g., in the form of marginal glosses. ${ }^{101}$ Works on theology included comparable representations from at least the 12th century onwards. ${ }^{102}$ The advent of printing made such tabular representations significantly cheaper and easier to produce. ${ }^{103}$ As a result, on top of works written in running prose (the most common form), from the 16th century onwards, canonists and moral theologians also made use of tabulae, sometimes with additional comments. ${ }^{104}$ This practice, which served not least a didactic purpose, continued into the 2oth century, particularly in theology. ${ }^{105}$

100 [Tarquini,] Institutionum juris canonici tabulae synopticae, 1835. For the person, see Fantappiè, Chiesa romana e modernità giuridica, vol. 1, 158-163; Nacci, Origini, sviluppi e caratteri del jus publicum ecclesiasticum, 6o-79.

101 Meyer, Die Distinktionstechnik in der Kanonistik des 12. Jahrhunderts; Meyer, "Spuren im Wald der Erinnerung"; Speer, "Verstehenshilfen zum geschriebenen Recht Medienwandel als Chance", 239-242; Wittekind, "Überlegungen zur Verwendung graphischer Marginalien in Rechtshandschriften ausgehend von Dom-Handschrift 127"; Dusil, "Visuelle Wissensvermittlung in der Gratian-Handschrift Köln, Diözesan- und Dombibliothek, 128". See also Stein, "Alte und neue Übersichtstafeln"; Schadt, Die Darstellungen der Arbores Consanguinitatis und der Arbores Affinitatis; Musson, "Seeing Justice: The Visual Culture of the Law and Lawyers"; Blair, Too Much to Know, 144-152; Röhl, "(Juristisches) Wissen über Bilder vermitteln".

102 Moore, The Works of Peter of Poitiers Master in Theology and Chancellor of Paris (11931205), 81-83; Robert Grosseteste, Templum dei, eds. Goering and Mantello.

103 Holthöfer, "Die Literatur zum gemeinen und partikularen Recht in Italien, Frankreich, Spanien und Portugal”, 135; Prinz, Der Bildgebrauch in gedruckten Rechtsbüchern des 15. bis zum Ausgang des 18. Jahrhunderts. See also Brendecke, "Information in tabellarischer Disposition".

104 See, for example: Girardus, Tituli totius iuris caesarei et pontificii per tabulas; Haemstedius, Tabulae totius sacrosancti iuris canonici; Tinctus, Tabulae sive introductiones; Ugolinus, De sacramentis novae legis tabulae perutiles; Pacius a Beriga, Oeconomia iuris utriusque; Le Masson, Theologia practica per tabulas distincta et exposita, 3 vols.; Kurtz, Amussis canonica, 5 vols.; Goritia, Epitome theologiae canonico-moralis; Cappelli, Manuale juris canonici. For some observations on this practice, see Wex, Ariadne carolino-canonica, Tabula IV, membrum IV, pp. 21-22. On Protestant moral theology, see e.g. Olearius, Doctrina theologiae moralis totius; Buddeus, Institutiones theologiae moralis in tabulis synopticis; Walchius, Theologiae moralis epitome tabulis analyticis expressa.

105 See e.g. Manassero, Tabulae synopticae theologiae moralis, 4 vols.; Berthier, Tabulae systematicae et synopticae totius Summae theologicae. See also [Anon.,] Rerum canonicarum scriptores; Santamaria, Tabulae synopticae Codicis Iuris Canonici. 
4

TAB. III.

D E J U R E C A N O N I C O ( ad Cap. 3. 4. Proleg.)

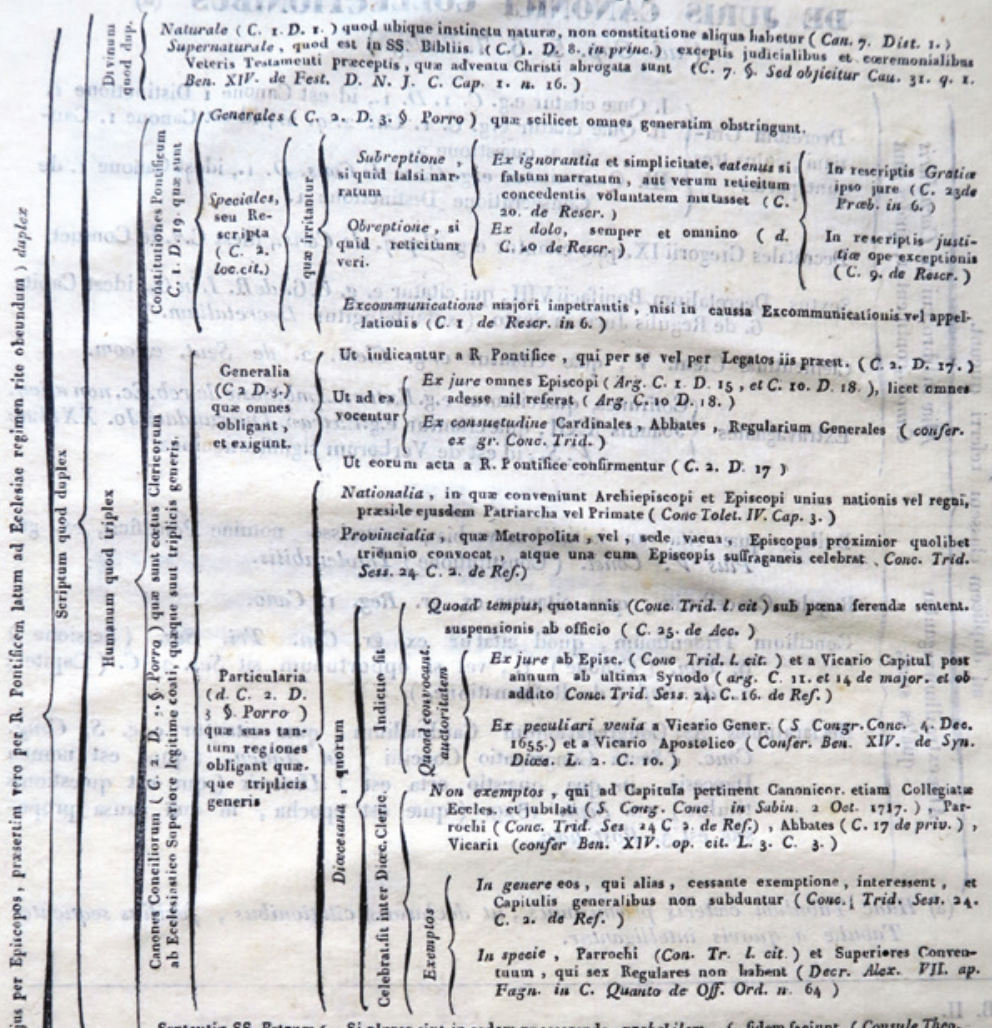

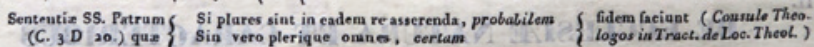
nuntiatum est, et ab Ecelesia sem. (Divina (Cunc. Trid. Sess, $4, \dot{\text { ) }}$ que Deum habet asctorem.

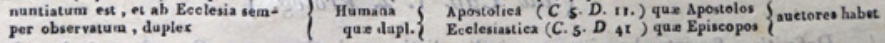

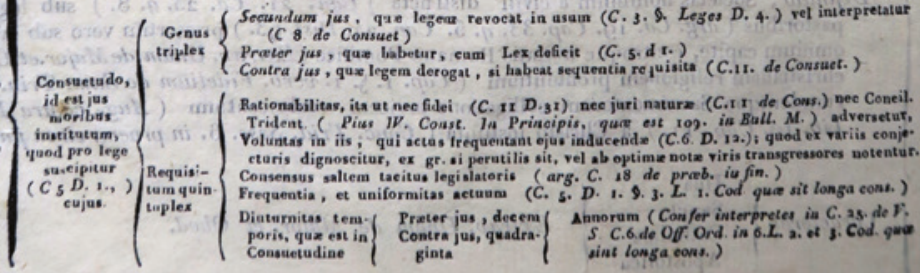

FIGU RE 2.1 [Camillo Tarquini:] Institutionum juris canonici tabulae synopticae juxta ordinem habitum a Joanne Devoti, Rome 1835, 4

PHOTO: OTTO DANWERTH 
This brings us back to Tarquini's work, which found readers also in perhaps unexpected quarters. The book was not only reprinted as soon as five years after its publication. ${ }^{106}$ It was also published in an annotated and somewhat reworked version by Jean-François-Marie Lequeux (17961866). ${ }^{107}$ This is particularly remarkable because, unlike Devoti and Tarquini, Lequeux did not belong to the group of Curial authors, but instead was a late representative of Gallicanism. ${ }^{108}$ The fact that Lequeux took an interest in Tarquini's tables in the first place, is probably due to his teaching at the Seminary of St. Sulpice in Paris where Devoti's Institutiones had been the prescribed textbook for canon law since $1836 .{ }^{109}$ In 1845 Lequeux anonymously published a version of Tarquini's tables that met the needs of Gallican readers. ${ }^{110}$ The two major changes to the work can already be gathered from the title. First, Lequeux indicated the passages where Gallican Church discipline supposedly differed from common canon law, Lequeux had indicated this by annotations. Second, these footnotes mostly refer to the second edition of his manual of canon law published in $1843^{-1844}{ }^{111}$ The latter was put on the Index in 1851, immediately after the publication of its third edition $(1850-1851) .{ }^{112}$

Lequeux's interest in the tabulae only becomes understandable if one takes into account the didactic value he placed on them, not only for beginners but especially for more advanced students of canon law. ${ }^{113}$ This leads to the question of the particular characteristics of Tarquini's work. Three aspects are particularly noteworthy in this respect. First, Tarquini started not from the sources of canon law itself; although he provided numerous references to legal sources, these all derived from a single work of canonistic scholarship. Second, he did not work eclectically, but rather focused on producing a graphical and tabular epitome of Devoti's textbook. Third and finally, an epigraph suggests that the work might have been inspired by a treatise of the Protestant philosopher and

\footnotetext{
106 [Tarquini,] Institutionum juris canonici tabulae synopticae, 1840.

107 Aubert, "Lequeux (Jean François Marie)".

108 On Gallicanism in general, see Gaudemet, "Les vicissitudes du Gallicanisme"; BasdevantGaudemet, Histoire du droit canonique et des institutions de l'Église latine, 486-523.

109 Mosiek, Die probati auctores in den Ehenichtigkeitsprozessen der S.R. Rota, 41.

110 [Tarquini,] Synopsis juris canonici. For the author, see Hurter, Nomenclator literarius theologiae catholicae, vol. 5,1, col. 1353 .

111 Lequeux, Manuale compendium juris canonici ad usum seminariorum, 4 vols.

112 Gough, Paris and Rome, 151-161; De Franceschi, "La papauté intransigeante et ses craintes d'un renouveau de régalisme gallican".

113 [Tarquini,] Synopsis juris canonici, I.
} 
jurist Christian Wolff (1679-1754), who had studied the design and use of mnemonic tables a century earlier. ${ }^{114}$

The recourse to mnemonic techniques intended to help readers learn and remember key conceptual matrices of canon law ${ }^{115}$ reveals an aspect of epitomisation that raises broader questions about the relationship between text and conceptual content. To the extent that the scholastic method, which predominated in the science of canon law until well into the 18th century, was based on "thinking along the text" (Rolf Schönberger), ${ }^{116}$ it would also seem to reflect the particular effect of epitomisation. Accordingly, the key principle was working on the text, which sometimes led to transformations of legal concepts.

Since Tarquini's tabulae continued a tradition of schematic, tabular representations that stretched back well into the Middle Ages, epitomisation might have given rise to further benefits. This emerges more clearly if we bear in mind that the silva legum was not only a forest of laws, but also a thicket of legal terminology and rules. If an epitomator's schematic representations prove that he had a clear conception of the order of legal concepts and rules, perhaps his work did more than clear a path through the forest of legal texts. This brings us back to the possibilities for abstraction inherent in epitomisation. As already suggested above, ${ }^{117}$ it is doubtful that we will find much evidence of this in early medieval epitomes. However, it is not unlikely that in the second millennium, particularly in the early modern and modern periods, we might be able to identify quite a number of such instances. This may be a fruitful subject for further study, particularly considering the important role played by epitomes or texts involving epitomisation in pre-modern legislation..118

114 [Tarquini,] Institutionum juris canonici tabulae synopticae, 1835, 2: "Ingens sane subsidium memoriae in Tabulis consistit, in quas doctrinae ita referuntur, ut uno quasi conspectu comprehendi earum ambitus possit. Christian. Wolph. Disert. de Tabular. Mnemonic. construct. et usu". See Wolfius, Tabularum Mnemonicarum constructio et usus, 470-471. See also Fantappiè, Chiesa romana e modernità giuridica, vol. 1, 163 fn. 158 .

115 See fn. 63 above. See also Heimann-Seelbach, "Diagrammatik und Gedächtniskunst".

116 Schönberger, Was ist Scholastik?, 83 ('Denken am Text').

117 See p. 49.

118 See, for example, the significance of epitomes for late medieval and (early) modern legislation. Thus the Principia iuris canonici, a compendium (and popular text book) produced by Georg Ludwig Böhmer (1715-1797), in which he condensed his father Henning Böhmer's (1674-1749) more substantial work, formed the basis of the sections on ecclesiastical law in the General Law Code for the Prussian States (Allgemeines Landrecht für die Preußischen Staaten) of 1794. See Richter, Beiträge zum Preussischen Kirchenrechte, 11; Dove, "Aemilius Ludwig Richter", 297 fn. 17; Schulte, Die Geschichte der Quellen und Literatur des canonischen Rechts, vol. 3.2-3, 136; Löhr, Das Preußische Allgemeine Landrecht und die Katholischen Kirchengesellschaften, 20 fn. 2, 116 fn. 1. For more information on Böhmer 


\section{Bibliography}

\section{Printed Sources}

Adnotationes codicum domini Justiniani (Summa Perusina), ed. Patetta, Federico (Bulletino dell'Istituto di diritto romano 12 (1900)), Roma 1900.

Alanus de Insulis, Liber in distinctionibus dictionum theologicalium, in Patrologiae cursus completus [...]. Series latina, accurante J.-P. Migne, vol. 210, Paris 1855, col. 685-1012.

[Anon.,] Rerum canonicarum scriptores. Tabulae synopticae ab anno 1141 ad annum 1564, in Jus pontificium 10 (1930), 83-92.

Archives legislatives de la ville de Reims, vol. 2.1, ed. Varin, Pierre, Paris 1847.

Bacon, Francis, De augmentisscientiarum, in The Works of Francis Bacon, vol. 1, eds. Spedding, James, Robert Leslie Ellis and Douglas Denon Heath, London 1858, 415-837.

Bartholomaeus Ugolinus, De sacramentis novae legis tabulae perutiles, Rimini 1587: Typis Ioannis Simbenei.

Becker, Clemens, Compendium juris decretalium ex ipsis decretalibus collectum [...], Munster 1772: Typis et sumptibus Anton. Wilh. Aschendorf.

Becker, Clemens, Decretum Gratiani abbreviatum [...], Munster 1781: Typis et sumptibus Anton. Wilh. Aschendorf.

Berthier, Joachim Joseph, Tabulae systematicae et synopticae totius Summae theologicae juxta ipsammet Doctoris Angelici methodum strictius et clarius exactae, Paris 1931.

Brancatus, Laurentius, Epitome canonum omnium [...], Rome 1659: Typis Mascardi.

Buddeus, Joh. Franciscus, Institutiones theologiae moralis in tabulis synopticis repraesentatas, in gratiam theologiae studiosorum, ut totum theologiae moralis ambitum, in mappa quasi delineatum, uno conspectu intueri possint, evulgare, ac omnibus doctrinam in compendio amantibus consecrare voluitJoh. Anton Strubberg, Jena/Leipzig 1721: Apud Johannem Martinum Gollnerum.

Canciani, Paulus, Praefatio Collectoris, in Barbarorum leges antiquae cum notis et glossariis, vol. 1, ed. Canciani, Paulus, Venice 1781: Apud Sebastianum Coletium et Franciscum Pitterium, IX-XX.

Canus, Melchior, De locis theologicis libri duodecim, Salamanca 1563: Excudebat Mathias Gastius.

Cappelli, Aloysius, Manuale juris canonici quod in usum auditorum quinquaginta tabulis synopticis delineavit et brevibus notis illustravit, Vilnius 1819.

[Casaubon, Isaac,] Henrico IV. Franciae et Navarrae Regi Christianissimo, Isaacus Casaubonus S.D., in Isaaci Casauboni epistolae, insertis ad easdem responsionibus, [...],

père et fils, see De Wall, “Böhmer, Georg Ludwig”; De Wall, “Böhmer, Justus Henning”. See also Varga, Codification as a Socio-Historical Phenomenon, 298-299. 
curante Theodoro Janson. ab Almeloveen, Rotterdam 1709: Typis Casparis Fritsch et Michaelis Böhm, 54-89.

Codex Iustinianus, ed. Krüger, Paul, 15th ed., Dublin 1970.

Devoti, Joannis, Institutionum canonicarum libri IV, 4 vols., Rome 1785-1789: Excudebat Giunchi librorum Bibliothecae Vaticanae provisor.

Doujat, Joannes, Praenotionum canonicarum libri quinque: quibus sacri juris atque universi studi ecclesiastici principia enucleantur, Venice 1717: Ex typographia Balleonii.

Étienne de Tournai, Lettres, ed. Desilve, Jules, Valenciennes 1893.

Ferreres, Juan B., Epitome theologiae moralis codicis canonici praescriptionibus, ac subsequentibus Sanctae Sedis declarationibus, dispositionibus iuris Hispani ac Lusitani, decretis Concilii Plenarii Americae Latinae necnon I Conc. Prov. Manilani, earundemque regionum legibus peculiaribus etiam civilibus accomodata, 4th ed., Barcelona 1933 .

Florens, Franciscus, Oratio in aperiendis scholis iuris habita VI. Non. Octob. anno M.DC XXXII. ad IX. tractatum calcem edita anno 1641. De recta iuris canonici discendi ratione, in Franciscus Florens: Opera juridica, vol. 1, Paris 1679: Sumptibus Joannis de la Caille, via Jacobaea, ad insigne Prudentiae, 59-63.

Gerbert, Martinus, Apparatus ad eruditionem theologicam, institutioni tironum Congregationis S. Blasii O.S.B. in silva nigra destinatus, Augsburg/Freiburg 1754: Sumptibus Ignatii et Antonii Wagner fratrum, typis Joannis Georgii Felner, Univers. typ.

Girardus, Iacobus, Tituli totius iuris caesarei et pontificii per tabulas, iuxta literarum ordinem, seiunctim digesti [...], Lyon 1551: Apud Michaelem Syluium Typographum.

Goritia, Franciscus Antonius a, Epitome theologiae canonico-moralis omnes seorsim in bis centis triginta tribus tabulis clare distincte ac breviter materias practicas exhibens, confessariorum, examinatorum, necnon examinandorum usibus accommodata, Rome 1796: In typographio Paleariniano.

Gregorius Magnus, Moralia in Iob, libri I-X, ed. Adriaen, Marc (Corpus Christianorum, Series latina, vol. 143), Turnhout 1979.

Grosseteste, Robert, Templum Dei edited from Ms. 27 of Emmanuel College, Cambridge, eds. Goering, Joseph and Frank A.C. Mantello, Toronto 1984.

Haemstedius, Hadrianus Cornelius, Tabulae totius sacrosancti iuris canonici, Louvain 1552: Prostant apud Martinum Rotarium, Bibliopolam Iuratum.

[Hieronymus,] Epistula Hieronymi adversus Rufinum presbyterum, in S. Hieronymi presbyteri opera, Pars III: Opera polemica, vol. 1, ed. Lardet, Pierre (Corpus Christianorum, Series latina, vol. 79), Turnhout 1982, 73-116.

Iuliani Epitome latina Novellarum Iustiniani, ed. Hänel, Gustav, Leipzig 1873.

Kurtz, Hermannus, Amussis canonica titulorum libri [...] Gregorii IX. pontificis maximi in tabulis mnemonicis analytice proposita [...], 5 vols., Prague 1761, 1762, 1764: Typis Archi-Episcopalibus per Jacobum Schweiger Archi-Episcopalem Typographum. 
Le Masson, Innocentius, Theologia practica per tabulas distincta et exposita [...], 3 vols., Paris 1662-1663: Apud Georgium Josse.

Legis Romanae Wisigothorum fragmenta ex codice palimpsesto sanctae Legionensis ecclesiae prostulit, illustravit ac sumptu publico edidit Regia Historiae Academia Hispana, Madrid 1896.

Lequeux, Jean-François-Marie, Manuale compendium juris canonici ad usum seminariorum, juxta temporum circumstantias accomodatum, 4 vols., 2nd ed., Paris 1843-1844.

Lex Romana Visigothorum, ed. Hänel, Gustav, Leipzig 1849 (repr. Aalen 1962).

[Luther, Martin,] D. Martin Luthers Werke. Kritische Gesamtausgabe, vol. 5: Tischreden aus den Jahren 1544-1544, ed. Komission zur Herausgabe der Werke Martin Luthers, Weimar 1919 .

Manassero, Bartholomaeus, Tabulae synopticae theologiae moralis e probatis auctoribus desumptae, 4 vols., 2nd ed., Rome 1903-1907.

Mansi, Joannes Dominicus, Epitome doctrinae moralis, et canonicae ex constitutionibus aliisque operibus felicis recordationis Benedicti XIV. pontificis maximi, Rome 1763: Sumptibus Remondianis.

Maranta, Carolus, Medulla Decreti alphabeticis distinctis litteris in qua quicquid in Decreto continetur per propositiones distinctas producitur; atque ex sanctorum patrum et conciliorum verbis fundatur; necnon aliquoties doctorum atque etiam sacrorum theologorum auctoritate fulcitur [...], Naples 1656: Ex Typographia Camilli Caualli.

Mesnartius, Martinus, Legum pontificiarum Gregorii noui, seu Decretalium pentateuchus in Epitomen arte et ordine reuocatus, seruata quadantenus antiquae legislationis maiestati et phrasi, Paris 1555: Apud Carolam Guillard sub sole aureo, et Gulielmum Guillard sub diuae Barbare signo, via Iacobaea.

Olearius, Johannes, Doctrina theologiae moralis totius, in usum incipientium, certis paediae ac methodi limitibus circumscripta et tabulis LXXII. comprehensa, Leipzig 1694: Sumptibus Joh. Christ. Wohlfarti, Bibliopol.

Pacius a Beriga, Iulius, Oeconomia iuris utriusque, tam civilis, quam canonici, perspicuis tabulis ad memoriam iuvandam repraesentata, et annotationibus illustrata, Lyon 1616: Sumptibus viduae Antonij de Harsy. Ad insigne Scuti Coloniensis.

Petrus Blesensis, Epistolae, in Patrologiae cursus completus [...]. Series latina, accurante J.-P. Migne, vol. 207, Paris 1855, col. 1-560.

Petrus Lombardus, Sententiae in IV libris distinctae. Liber I et II, vol. 1, 3rd ed., Grottaferrata 1971.

Pichler, Vitus, Candidatus jurisprudentiae sacrae, seu juris canonici secundum Gregorii Papae IX. decretalium titulos explanati [...], 5 vols., Augsburg/Dillingen 1716-1721: Sumptibus Georgij Schlüter et Martini Happach, Bibliop., et typis viduae Joannis Mauritij Körner, Typogr. Episc.

Pichler, Vitus, Candidatus abbreviatus jurisprudentiae sacrae. Hoc est, juris canonici secundum Gregorii Papae IX. libros V. decretalium explanati summa seu compendium, 
quod in usum maxime discipulorum suorum ex libris suis collegit auctor ipse [...], 2 vols., Augsburg 1731: Sumptibus Martini Happach, et Franc. Xav. Schlüter.

Reformation de l'Université de Paris, Paris 1601: Chez I. Mettayer et P. l'Huillier imprimeurs et libraires ordinaires du Roy.

Rives, Gregorius de, Epitome canonum conciliorum in locos communes per alphabetum digesta [...], Lyon 1663: Sumpt. Benedicti Coral, in vico Mercatorio sub signo Victoriae.

Santamaria, Alberto, Tabulae synopticae Codicis Iuris Canonici, Manila 1949.

Schram, Dominicus, Epitome canonum ecclesiasticorum ex conciliis Germaniae et aliis fontibus juris ecclesiastici Germanici collecta, ac ordine alphabeti secundum materias distincta, Augsburg 1774: Sumptibus Matthaei Rieger et filiorum.

Scortia, Joannis Baptista, In selectas summorum pontificum constitutiones epitome, ac theoremata, Lyon 1625: Sumpt. Ludovici Prost, haeredis Roville.

[Seneca,] L. Annaeii Senecae ad Lucilium epistulae morales, vol. 2, ed. Reynolds, L.D., Oxford 1965 .

Serraino, Mario, Epitome juris canonici. Ad mentem Codicis 1983, Trapani 1988.

[Simon of Bisignano,] Summa in Decretum Simonis Bisinianensis, ed. Aimone Braida, Pier V., Vatican City 2014.

[Tarquini, Camillo,] Institutionum juris canonici tabulae synopticae juxta ordinem habitum a Joanne Devoti, Rome 1835 .

[Tarquini, Camillo,] Institutionum juris canonici tabulae synopticae juxta ordinem habitum a Joanne Devoti, Florence 1840.

[Tarquini, Camillo,] Synopsis juris canonici communis secundum ordinem institutionum J. Devoti per tabulas disposita. Opusculum e selectissimis doctorum utriusque juris operibus collectum. In hac Parisiensi editione indicantur praecipua disciplinae gallicanae a jure communi discrimina per opportunas remissiones ad Manuale compendium juris canonici D. Lequex majoris seminarii Suessionensis moderatoris, Paris 1845 .

Telch, Carolus, Epitome theologiae moralis universae per definitiones, divisiones et summaria principia pro recollectione moralis et ad immediatum usum confessarii et parochi excerpta e Summa theol. mor. R.P. Hier. Noldin SJ, 6th ed., Innsbruck 1924.

Tertullianus, Quintus Septimius Florens, Apologeticum, ed. Dekkers, Eligius, in Quinti Septimi Florentis Tertulliani opera, Pars I (Corpus Christianorum, Series latina, vol. 1), Turnhout 1950, 77-171.

The Hibernensis. A Study and Edition, ed. Flechner, Roy, Book 1, Washington D.C. 2019. Theodosiani libri XVI cum constitutionibus Sirmondianis et leges novellae ad Theodosianum pertinentes, 2 vols., eds. Mommsen, Theodor and Paul M. Meyer, 3rd ed., Berlin 1962.

Tinctus, Iulius Caesar, Tabulae sive introductiones in institution[es] iuris canonici in IIII libros distinctae, Ferrara 1583: Excudebat Victorius Baldinus. 
[Vacarius,] The Liber Pauperum of Vacarius, ed. Zulueta, Francis de, London 1927.

Vermeersch, Arthur and Joseph Creusen, Epitome iuris canonici cum commentariis ad scholas et ad usum privatum, 3 vols., 7 th ed., Mechlin 1949-1956.

Walchius, Ioannis Georgius, Theologiae moralis epitome tabulis analyticis expressa, Jena 1758: Apud Io. Rudolph. Croecker. viduam.

Wex, Jacobus, Ariadne carolino-canonica, seu doctrina theorico-practica ss. canonum, Augsburg/Dillingen 1708: Apud Joannem Casparum Bencard.

Wolfius, Christianus, Tabularum Mnemonicarum constructio et usus, in Wolf, Christian, Horae subsecivae Marburgenses, vol. 2, Frankfurt/Leipzig 1732: Prostat in bibliop. Rengeriano, 468-513.

\section{Literature}

Adam, Wolfgang, Poetische und kritische Wälder. Untersuchungen zu Geschichte und Formen des Schreibens „, bei Gelegenheit“, Heidelberg 1988.

Aimone, Pier V., "Alcune note sulla Abbreviatio Dunelmensis della Summa Simonis Bisinianensis", in Goering, Joseph, Stephan Dusil and Andreas Thier (eds.), Proceedings of the Fourteenth International Congress of Medieval Canon Law. Toronto, 5-11 August 2012, Vatican City 2016, 179-197.

Alfieri, Fernanda, Nella camera degli sposi. Tomás Sánchez, il matrimonio, la sessualità (secoliXVI-XVII), Bologna 2010.

Angelini, Paolo, “Annotazioni sull'epitome greca dell'Editto di Rotari”, Historia et ius 3 (2015), 1-13 (http://www.historiaetius.eu/uploads/5/9/4/8/5948821/angelini_7.pdf).

[Anon.,] "Alfred von Halban", in Österreichischen Akademie der Wissenschaften (ed.), Österreichisches Biographisches Lexikon 1815-1950, vol. 2, Graz 1959, 157.

Arrieta, Juan Ignacio, "Fuero interno", in Diccionario general de derecho canónico, vol. 4, Cizur Menor 2012, 139-144.

Atzeri, Lorena, Gesta sentus Romani de Theodosiano publicando. Il Codice Teodosiano e la sua diffusione ufficiale in Occidente, Berlin 2008.

Aubert, R., "Lequeux (Jean François Marie)", in Dictionnaire d'histoire et de géographie ecclésiastiques, vol. 31, Paris 2015, col. 856-857.

Basdevant-Gaudemet, Brigitte, Histoire du droit canonique et des institutions de l'Église latine. $X V^{e}-X X^{e}$ siècle, Paris 2014.

Becker, Hans-Jürgen, "Das kanonische Recht im vorreformatorischen Zeitalter", in Boockmann, Hartmut, Ludger Grenzmann, Bernd Moeller and Martin Staehelin (eds.), Recht und Verfassung im Übergang vom Mittelalter zur Neuzeit, vol. 1, Göttingen 1998, 9-24.

Bergfeld, Christoph, "Katholische Moraltheologie und Naturrechtslehre", in Coing, Helmut (ed.), Handbuch der Quellen und Literatur der neueren europäischen Privatrechtsgeschichte, vol 2.1: Neuere Zeit (1500-1800). Das Zeitalter des gemeinen Rechts, Munich 1977, 999-1033. 
Bertram, Martin, "Casus legum sive suffragia monachorum. Legistische Hilfsmittel für Kanonisten im späteren Mittelalter (unter Mitarbeit von Marguerite Duynstee)", in Tijdschrift voor Rechtsgeschiedenis 51 (1983), 317-363 (reprint Bertram, Martin, Kanonisten und ihre Texte (1234 bis Mitte 14. Jh.). 18 Aufsätze und 14 Exkurse, Leiden 2013, 37-9o).

Beyer, Alfred, Lokale Abbreviationen des Decretum Gratiani. Analyse und Vergleich der Dekretabbreviationen "Omnes leges aut divine" (Bamberg), "Humanum genus duobus regitur" (Pommersfelden) und "De his qui intra clausura monasterii consistunt" (Lichtenthal, Baden-Baden), Frankfurt 1998.

Black, Winston, "Teaching the Mnemonic Bishop in the Medieval Canon Law Classroom", in Danielson, Sigrid and Evan A. Gatti (eds.), Envisioning the Bishop: Images and the Episcopacy in the Middle Ages, Turnhout 2014, 377-404.

Blair, Ann M., Too Much to Know. Managing Scholarly Information before the Modern Age, New Haven, CT 2010.

Boehmer, Heinrich, "Luther und der 10. Dezember 1520", in Luther-Jahrbuch 2-3 (19201921), 7-53.

Boyle, Leonard E., "Summae confessorum", in Bultot, Robert (ed.), Les genres littéraires dans les sources théologiques et philosophiques médiévales. Définition, critique et exploitation. Actes du Colloque international de Louvain-la-Neuve 25-27 mai 1981, Louvain-la-Neuve 1982, 227-237.

Brasington, Bruce C., “The Abbreviatio 'Exceptiones evangelicarum'. A Distinctive Regional Reception of Gratian's Decretum”, in Codices manuscripti 17 (1994), 95-99.

Brendecke, Arndt, "Information in tabellarischer Disposition", in Grunert, Frank and Anette Syndikus (eds.), Wissensspeicher der Frühen Neuzeit. Formen und Funktionen, Berlin 2015, 43-59.

Brundage, James A., "E pluribus unum: Custom, the Professionalization of Medieval Law, and Regional Variations in Marriage Formation", in Korpiola, Mia (ed.), Regional Variations in Matrimonial Law and Custom in Europe, 1150-16oo, Leiden 2011, 21-41.

Buzzi, Franco, "La tradizione teologica milanese tra Cinque e Seicento", in Studia Borromaica 21 (2007), 129-163.

Carrodeguas, Celestino, La sacramentalidad del matrimonio. Doctrina de Tomás Sánchez, S.J., Madrid 2003.

Chadwick, Henry, "Florilegium", in Reallexikon für Antike und Christentum, vol. 7, Stuttgart 1969, col. 1131-116o.

Coma Fort, José Maria, Codex Theodosianus. Historia de un texto, Madrid 2014.

Conrat (Cohn), Max, Geschichte der Quellen und Literatur des römischen Rechts im früheren Mittelalter, vol. 1, Leipzig 1891 (repr. Aalen 1963).

Contreni, John J., "The Biblical Glosses of Haimo of Auxerre and John Scottus Eriugena", in Speculum $5^{1}$ (1976), 411-434. 
Contreni, John J., "Three Carolingian Texts from Laon: Reconsiderations", in Studi medievali 17 (1976), 797-813.

Contreni, John J., The Cathedral School of Laon from 850 to 930. Its Manuscripts and Masters, Munich 1978.

Cuena Boy, Francisco, “Exceso de leyes en Roma: ¿retórica o realidad?”, in Annaeus 4 (2007), 3-27.

Dannenberg, Lars-Arne, “Der lange Arm des Gesetzes. Zur Stellung der franziskanischen Ordensorganisation im Lichte der Vorgaben des kirchlichen ius commune unter besonderer Berücksichtigung der Titelsumme Heinrichs von Merseburg", in Robson, Michael and Jens Röhrkasten (eds.), Franciscan Organisation in the Mendicant Context. Formal and informal structures of the friars' lives and ministry in the Middle Ages, Munster 2010, 331-352.

De Franceschi, Sylvio Hermann, "La papauté intransigeante et ses craintes d'un renouveau de régalisme gallican: La mise à l'Index du Manuale compendium iuris canonici de l'abbé Jean-François-Marie Lequeux", in De Franceschi, Sylvio Hermann and Bernard Hours (eds.), Droits antiromains. Juridictionalisme catholique et romanité ecclésiale (XVI ${ }^{e}-X I X^{e}$ siècles), Lyon 2017, 215-253.

De Wall, Heinrich, "Böhmer, Georg Ludwig”, in Handwörterbuch zur deutschen Rechtsgeschichte, 2nd ed., Berlin 2008, col.639.

De Wall, Heinrich, “Böhmer, Justus Henning”, in Handwörterbuch zur deutschen Rechtsgeschichte, vol. 1, 2nd ed., Berlin 2008, col. 640-641.

Dell'Olmo, Luciano and Rino Scuccimarra, Il beato Angelo Carletti da Chiavasso e le edizioni della Summa Angelica nei secoli XV e XVI, Chiavasso 1983.

Di Cintio, Lucia, L'«Interpretatio Visigothorum» al «Codex Theodosianus». Il libro IX, Milan 2013.

Di Cintio, Lucia, Nuove ricerche sulla «Interpretatio Visigothorum» al «Codex Theodosianus». Libri I-II, Milan 2018.

Doering, Lutz, "Fort- und Neuschreibung autoritativer Texte und Identitätsbildung im Jubiläenbuch sowie in Texten aus Qumran”, in Grohmann, Marianne (ed.), Identität und Schrift. Fortschreibungsprozesse als Mittel religiöser Identitätsbildung, Göttingen 2017, 69-103.

Dolezalek, Gero and Rudolf Weigand, "Das Geheimnis der roten Zeichen. Ein Beitrag zur Paläographie juristischer Handschriften des zwölften Jahrhunderts”, in Zeitschrift der Savigny-Stiftung für Rechtsgeschichte. Kanonistische Abteilung 69 (1983), 143-199.

Dove, Richard Wilhelm, "Aemilius Ludwig Richter", in Zeitschrift für Kirchenrecht 7 (1867), 273-404.

Dubischar, Markus, "Preserved Knowledge. Summaries and Compilations", in Hose, Martin and David Schenker (eds.), A Companion to Greek Literature, Chichester 2016, 427-440. 
Dusil, Stephan, "Visuelle Wissensvermittlung in der Gratian-Handschrift Köln, Diözesan- und Dombibliothek, 128”, in Horst, Harald (ed.), Mittelalterliche Handschriften der Kölner Dombibliothek. Siebtes Symposion der Diözesan- und Dombibliothek Köln zu den Dom-Manuskripten (25. und 26. November 2016), Cologne 2018, 115-137.

Dusil, Stephan, “The Decretum of Gratian: A Janus-Faced Collection”, in Rolker, Christof (ed.), New Discourses in Medieval Canon Law Research. Challenging the Master Narrative, Leiden 2019, 127-144.

Dusil, Stephan, Gerald Schwedler and Raphael Schwitter (eds.), Exzerpieren - Kompilieren - Tradieren. Transformationen des Wissens zwischen Spätantike und Frühmittelalter, Berlin 2017.

Dusil, Stephan, Gerald Schwedler and Raphael Schwitter, "Transformationen des Wissens zwischen Spätantike und Frühmittelalter. Zur Einführung”, in Dusil, Stephan, Gerald Schwedler and Raphael Schwitter (eds.), Exzerpieren - Kompilieren - Tradieren. Transformationen des Wissens zwischen Spätantike und Frühmittelalter, Berlin 2017, 1-22.

Duval, André, "La Summa Conciliorum de Barthélemy Carranza", in Revue des sciences philosophiques et théologiques 41 (1957), 401-427.

Ertl, Thomas, Religion und Disziplin. Selbstdeutung und Weltordnung im frühen deutschen Franziskanertum, Berlin 2006.

Fantappiè, Carlo, Chiesa romana e modernità giuridica, vol. 1: L'edificazione del sistema canonistica (1563-1903), Milan 2008.

Feola, Raffaele, "Canciani, Paolo", in Dizionario biografico degli Italiani, vol. 17, Rome 1974, 749-751.

Figueira, Robert C., "Ricardus de Mores and his Casus decretalium: the Birth of a Canonistic Genre", in Chodorow, Stanley (ed.), Proceedings of the Eighth International Congress of Medieval Canon Law. San Diego, University of California at La Jolla, 21-27 August 1988, Vatican City 1992, 168-187.

Fransen, Gérard, "Les abrégés de collections canoniques. Essai de typologie", in Revue de droit canonique 28 (1978), 157-166.

Fritsch, Matthias J., Religiöse Toleranz im Zeitalter der Aufklärung. Naturrechtliche Begründung - konfessionelle Differenzen, Hamburg 2004.

Frońska, Joanna, "Memory and the Making of Images: A Case of a Legal Manuscript", in Manuscripta 54 (2010), 1-20.

Frońska, Joanna, “Turning the Pages of Legal Manuscripts: Reading and Remembering the Law", in Zchomelidse, Nino and Giovanni Freni (eds.), Meaning in Motion. Semantics of Movement in Medieval Art, Princeton, NJ 2011, 191-214.

Frońska, Joanna, "The Memory of Roman Law in an Illuminated Manuscript of Justinian's Digest", in Brenner, Elma, Meredith Cohen and Mary Franklin-Brown (eds.), Memory and Commemoration in Medieval Culture, Farnham 2013, 163-179. 
Furtenbach, Siegfried and Herbert Kalb, "Die Rechtsliteratur in volkssprachiger Überlieferung in Österreich", in Reiffenstein, Ingo (ed.), Beiträge zur Überlieferung und Beschreibung deutscher Texte des Mittelalters, Göppingen 1983, 115-138.

Galdi, Marco, L'epitome nella letteratura latina, Naples 1922.

Ganivet, Pierre, "L'«epitomé de Lyon»: un témoin de la réception du Bréviaire dans le Sud-Est de la Gaule au VIe siècle?", in Rouche, Michel and Bruno Dumézil (eds.), Le Bréviaire d'Alaric. Aux origines du Code civil, Paris 2008, 279-328.

Gaudemet, Jean, Le Bréviaire d'Alaric et les Epitome, Milan 1965.

Gaudemet, Jean, "Les vicissitudes du Gallicanisme", in Studi in memoria di Pietro Gismondi, vol. 2, Rome 1991, 43-70 (reprint Gaudemet, Jean, La doctrine canonique médiévale, Aldershot 1994, XIII).

Gebhardt, Ulrich C.J., Sermo Iuris: Rechtssprache und Recht in der augusteischen Dichtung, Leiden 2009.

Goering, Joseph, “The Internal Forum and the Literature of Penance and Confession", in Hartmann, Wilfried and Kenneth Pennington (eds.), The History of Medieval Canon Law in the Classical Period, 140-1234. From Gratian to the Decretals of Pope Gregory IX, Washington, D.C. 2008, 379-428.

Gough, Austin, Paris and Rome. The Gallican Church and the Ultramontane Campaign, 1848-1853, Oxford 1986.

Grabmann, Martin, Die Geschichte der scholastischen Methode, vol. 2: Die scholastische Methode im 12. und beginnenden 13. Jahrhundert, Freiburg 1911 (repr. Graz 1957).

Grabmann, Martin, "Hilfsmittel des Thomasstudiums aus alter Zeit. (Abbreviationes, Concordantiae, Tabulae). Auf Grund handschriftlicher Forschungen dargestellt", in Grabmann, Martin (ed.), Mittelalterliches Geistesleben. Abhandlungen zur Geschichte der Scholastik und Mystik, vol. 2, Munich 1936, 424-489.

Grabmann, Martin, Methoden und Hilfsmittel des Aristotelesstudiums im Mittelalter, Munich 1939 (Sitzungsberichte der Bayerischen Akademie der Wissenschaften. Philosophisch-historische Abteilung, vol. 5).

Grabmann, Martin, "Das Weiterwirken des moraltheologischen Schrifttums des hl. Thomas von Aquin im Mittelalter", in Divus Thomas 24 (1947), 3-28 (reprint Steinbüchel, Theodor and Theodor Müncker (eds.), Aus Philosophie und Theologie. Festschrift für Fritz Tillmann zu seinem 75. Geburtstag (1. November 1949), Dusseldorf 1950, 64-83).

Grosso, Giuseppe, "Meditazione su Tacito, sulla moltiplicazione delle leggi e sugli attuali sviluppi costituzionali", in Studi in onore di Giuseppe Chiarelli, vol. 4, Milan 1974, 35०9-3519.

Guarino, Antonio, “La rimozione del diritto e l'esperienza romana”, in Labeo 42 (1996), $7-36$.

Halban, Alfred von, Das römische Recht in den germanischen Volksstaaten, vol. 2 \& vol. 3, Breslau 1901 \& 1907 . 
Hamesse, Jacqueline, "A propos de quelques techniques d'interprétation et de compilation des textes. Paraphrases, florilèges et compendia", in Meirinhos, José Francisco (ed.), Itinéraires de la raison. Études de philosophie médiévale offertes à Maria Cândida Pacheco, Louvain-la-Neuve 2005, 11-34.

Hamesse, Jacqueline, “«Florilège» et «autorité»: deux concepts en évolution depuis l'Antiquité jusqu'à la Renaissance", in Ceulemans, Reinhart and Pieter De Leemans (eds.), On Good Authority. Tradition, Compilation and the Construction of Authority in Literature from Antiquity to the Renaissance, Turnhout 2015, 199-225.

Harries, Jill, "Roman Law and Legal Culture", in Johnson, Scott Fitzgerald (ed.), The Oxford Handbook of Late Antiquity, Oxford 2012, 789-814.

Hathaway, Neil, “Compilatio: From Plagiarism to Compiling”, in Viator 20 (1989), 19-44. Heimann-Seelbach, Sabine, "Diagrammatik und Gedächtniskunst. Zur Bedeutung der Schrift für die Ars memorativa im 15. Jahrhundert”, in Kintzinger, Martin, Sönke Lorenz and Michael Walter (eds.), Schule und Schüler im Mittelalter. Beiträge zur europäischen Bildungsgeschichte des 9. bis 15. Jahrhunderts, Cologne 1996, 385-408.

Hess, Gilbert, "Florilegien. Genese, Wirkungsweisen und Transformationen frühneuzeitlicher Kompilationsliteratur", in Grunert, Frank and Anette Syndikus (eds.), Wissensspeicher der Frühen Neuzeit. Formen und Funktionen, Berlin 2015, 97-138.

Holthöfer, Ernst, "Die Literatur zum gemeinen und partikularen Recht in Italien, Frankreich, Spanien und Portugal", in Coing, Helmut (ed.), Handbuch der Quellen und Literatur der neueren europäischen Privatrechtsgeschichte, vol 2.1: Neuere Zeit (1500-1800). Das Zeitalter des gemeinen Rechts, Munich 1977, 103-499.

Honsell, Heinrich, "Der Gesetzesstil in der römischen Antike", in Giuffrè, Vincenzo (ed.), Sodalitas. Scritti in onore di Antonio Guarino, vol. 4, Naples 1984, 1659-1673.

Horn, Norbert, "Die legistische Literatur der Kommentatoren und der Ausbreitung des gelehrten Rechts", in Coing, Helmut (ed.), Handbuch der Quellen und Literatur der neueren europäischen Privatrechtsgeschichte, vol. 1: Mittelalter (1100-150o). Die gelehrten Rechte und die Gesetzgebung, Munich 1973, 261-364.

Horster, Marietta and Christiane Reitz (eds.), Condensing Texts - Condensed Texts, Stuttgart 2010.

Horster, Marietta and Christiane Reitz, "Handbooks, Epitomes, and Florilegia", in McGill, Scott and Edward J. Watts (eds.), A Companion to Late Antique Literature, New York 2018, 431-45o.

Hurter, Hugo, Nomenclator literarius theologiae catholicae, vol. 5,1, 3rd ed., Innsbruck 1911 (repr. New York 1963).

Hurtubise, Pierre, La casuistique dans tous ses états. De Martin Azpilcueta à Alphonse de Liguori, Montreal 2005.

Illich, Ivan, In the Vineyard of the Text. A Commentary to Hugh's Didascalicon, Chicago, IL 1993 . 
Kaiser, Wolfgang, "Vulgarrecht", in Der neue Pauly. Enzyklopädie der Antike, vol. 12.2, Stuttgart 2002, col. 350-351.

Kaiser, Wolfgang, Die Epitome Iuliani. Beiträge zum römischen Recht im frühen Mittelalter und zum byzantinischen Rechtsunterricht, Frankfurt 2004.

Kaiser, Wolfgang, "Verkürzt und wiederaufgefüllt? Review of: Ch. Radding/A. Ciaralli, The Corpus iuris in the Middle Ages. Manuscripts and Transmission from the Sixth Century to the Juristic Revival, Leiden/Boston 2007", in Rechtsgeschichte 11 (2007), 182-185.

Kaiser, Wolfgang, “Wandlungen im Verständnis der Epitome Iuliani von der Spätantike bis zur Gegenwart”, in Avenarius, Martin (ed.), Hermeneutik der Quellentexte des Römischen Rechts, Baden-Baden 2008, 300-353.

Kannengiesser, Charles, "Tyconius of Carthage, the Earliest Latin Theoretician of Biblical Hermeneutics. The current debate", in Maritano, Mario (ed.), Historiam perscrutari. Miscellanea di studi offerti al prof. Ottorino Pasquato, Rome 2002, 297-311.

Kästle-Lamparter, David, Welt der Kommentare. Struktur, Funktion und Stellenwert juristischer Kommentare in Geschichte und Gegenwart, Tübingen 2016.

Kéry, Lotte, Canonical Collections of the Early Middle Ages (ca. 400-1140). A Bibliographical Guide to the Manuscripts and Literature, Washington, D.C. 1999.

Kéry, Lotte, "Forum externum, Forum internum", in Handwörterbuch zur deutschen Rechtsgeschichte, vol. 1, 2nd ed., Berlin 2008, col. 1641-1643.

Kessler, Stephan C., "Gregor der Große und seine Theorie der Exegese: die Epistula ad Leandrum", in L'esegesi dei padri latini. Dalle origini a Gregorio Magno. XXVIII Incontro di studiosi dell'antichità cristiana, vol. 2, Rome 2000, 691-700.

Kimmel, Christina, "Abbreviatio des Decretum Gratiani mit Ergänzungen", in Berschin, Walter and Kurt Hans Staub (eds.), Fragmenta Darmstadiensia. Heidelberger Handschriften-Studien des Seminars für Lateinische Philologie des Mittelalters (III), Darmstadt 1997, 81-88.

Krüger, Paul, Geschichte der Quellen und Literatur des Römischen Rechts, 2nd ed., Munich 1912.

Kurtscheid, Bertrandus, "De studio juris canonici in Ordine Fratrum Minorum saeculo XIII", in Antonianum 2 (1927), 157-202.

Kuttner, Stephan, Repertorium der Kanonistik (1140-1234). Prodromus Corporis Glossarum, vol. 1, Vatican City 1937.

Kuttner, Stephan, "On the Place of Canon Law in a General History of Roman Law during the Middle Ages", in Seminar 13 (1955/1956), 51-55.

Kuttner, Stephan, "The Revival of Jurisprudence", in Benson, Robert L. and Giles Constable (eds.), Renaissance and Renewal in the Twelfth Century, Cambridge, MA 1982, 299-323 (reprint Kuttner, Stephan, Studies in the History of Medieval Canon Law, Aldershot 1990, (III), 5-7 (Retractationes)). 
L'Engle, Susan, "The Pro-Active Reader: Learning to Learn the Law", in Medieval Manuscripts, Their Makers and Users. A special issue of Viator in honor of Richard and Mary Rouse, Turnhout 2011, 51-75.

Laistner, Max L.W., "Notes on Greek from the Lectures of a Ninth Century Monastery Teacher", in Bulletin of the John Rylands Library 7 (1923), 421-456.

Lambertini, Renzo, La codificazione di Alarico II, 2nd ed., Turin 1991.

Lambertini, Renzo, “Sull'«Epitome Gai» nel «Breviarium»", in Labeo 41 (1995), 229-238.

Landau, Peter, "Die Breviatio canonum des Ferrandus in der Geschichte des kanonischen Rechts. Zugleich nochmals zur Benutzung der Dionysiana bei Gratian”, in Zapp, Hartmut, Andreas Weiß and Stefan Korta (eds.), Ius canonicum in oriente et occidente. Festschrift für Carl Gerold Fürst zum 7o. Geburtstag Frankfurt 2003, 297-309.

Landau, Peter, "Gratian and the Decretum Gratiani", in Hartmann, Wilfried and Kenneth Pennington (eds.), The History of Medieval Canon Law in the Classical Period, 1140-1234. From Gratian to the Decretals of Pope Gregory IX, Washington, D.C. 2008, 22-54.

Landau, Peter, “Gratian", in Handwörterbuch zur deutschen Rechtsgeschichte, vol. 2, 2nd ed., Berlin 2012, col. 530-533.

Larson, Atria A., "An Abbreviatio of the First Recension of Gratian's Decretum in $\mathrm{Mu}-$ nich?", in Bulletin of Medieval Canon Law 29 (2011/2012), 51-118.

Larson, Atria A., "Géneros literarios canónicos", in Otaduy, Javier, Antonio Viana and Joaquín Sedano (eds.), Diccionario general de derecho canónico, vol. 4, Cizur Menor 2012, 189-192.

Lauro, Agostino, "Devoti, Giovanni”, in Dizionario biografico degli italiani, vol. 39, Rome 1991, 598-6o3.

León, Enrique de, "La abreviación ‘quoniam egestas' del Decreto de Graciano”, in Erdö, Péter and Szabolcs Anzelm Szuromi (eds.), Proceedings of the Thirteenth International Congress of Medieval Canon Law. Esztergom, 3-8 August 2008, Vatican City 2010, 303-310.

León, Enrique de, “Abbreviatio”, in Diccionario general de derecho canónico, vol. 1, Cizur Menor 2012, 66-68.

Liebs, Detlef, Hermogenians iuris epitomae. Zum Stand der römischen Jurisprudenz im Zeitalter Diokletians, Göttingen 1964.

Liebs, Detlef, “'Variae lectiones' (Zwei Juristenschriften)”, in Studi in onore di Edoardo Volterra, vol. 5, Milan 1971, 51-88.

Liebs, Detlef, "Recht und Rechtsliteratur", in Herzog, Reinhart (ed.), Handbuch der lateinischen Literatur der Antike, vol. 5: Restauration und Erneuerung. Die lateinische Literatur von 284 bis 374 n.Chr., Munich 1989, 55-73.

Liebs, Detlef, “Jurisprudenz”, in Sallmann, Klaus (ed.), Handbuch der lateinischen Literatur der Antike, vol. 4: Die Literatur des Umbruchs. Von der römischen zur christlichen Literatur 117 bis 284 n. Chr., Munich 1997, 83-217. 
Liebs, Detlef, Römische Jurisprudenz in Gallien (2. bis 8. Jahrhundert), Berlin 2002.

Liebs, Detlef, “Zur Überlieferung und Entstehung des Breviarium Alaricianum”, in Crifò, Giuliano and Stefano Giglio (eds.), Atti dell'Accademia romanistica costantiniana. XIVConvegno internazionale in memoria di Guglielmo Nocera, Naples 2003, 653-671.

Liebs, Detlef, "Nachklassische römische Rechtsliteratur", in Thür, Gerhard (ed.), Antike Rechtsgeschichte. Einheit und Vielfalt, Vienna 2005, 27-42.

Liebs, Detlef, "Roman Vulgar Law in Late Antiquity", in Sirks, Boudewijn (ed.), Aspects of Law in Late Antiquity. Dedicated to A.M. Honoré on the occasion of the sixtieth year of his teaching in Oxford, Oxford 2008, 35-53.

Liebs, Detlef, "Das Verbot von Mischehen im germanisch-römischen Recht”, in Giglio, Stefano (ed.), Atti dell'Accademia romanistica costantiniana. XVII convegno internazionale in onore di Giuliano Crifo, vol. 1, Rome 2010, 622-628.

Liebs, Detlef, "Legis Romanae Visigothorum Epitomen Sangallensem traditam in codice 731 bibliothecae dictae Stiftsbibliothek descripto a Vandalgario mense Octobris anni 793 p. Chr. n. (paginis 1-230), cum praefatione ratiocinans transscripsit", in Zeitschrift der Savigny-Stiftung für Rechtsgeschichte. Romanistische Abteilung 129 (2012), 1-112.

Liebs, Detlef, "Römischrechtliche Glut aus dem 8. Jh. für ein Bischofsgericht in Burgund", in Liebs, Detlef, Das Recht der Römer und die Christen. Gesammelte Aufsätze in überarbeiteter Fassung, Tübingen 2015, 256-274.

Liebs, Detlef, "Scintilla de libro legum. L'Epitome Fuldense del Breviario Alariciano", in Bassanelli Sommariva, Gisella and Simona Tarozzi (eds.), Ravenna capitale. Codice Teodosiano e tradizioni giuridiche in Occidente. La terra, strumento di arricchimento e sopravivenza, Santarcangelo di Romagna 2016, 279-304.

Liebs, Detlef, "Warum endete gegen Mitte des 3. Jahrhunderts die klassische Rechtsliteratur?", in Eich, Armin, Stefan Freund, Meike Rühl and Christoph Schubert (eds.), Das dritte Jahrhundert. Kontinuitäten, Brüche, Übergänge. Ergebnisse der Tagung der Mommsen-Gesellschaft am 21.-22.11.2014 an der Bergischen Universität Wuppertal, Stuttgart 2017, 57-73.

Liebs, Detlef, "Wenn Fachliteratur Gesetz wird. Inwieweit wurden römische Juristenschriften im Laufe der Jahrhunderte überarbeitet?", in Zeitschrift der SavignyStiftung für Rechtsgeschichte. Romanistische Abteilung 135 (2018), 395-473.

Lizzi, Rita, "La memoria selettiva", in Cavallo, Guglielmo, Paolo Fedeli and Andrea Giardina (eds.), Lo spazio letterario di Roma antica, vol. 3, Rome 1990, 647-676.

Llauró, Juan, “Los glossarios de Ripoll”, in Analecta Sacra Tarraconensia 3 (1927), 331-389. Löhr, Joseph, Das Preußische Allgemeine Landrecht und die Katholischen Kirchengesellschaften, Paderborn 1917.

Mantovani, Dario, "Legum multitudo e dritto privato. Revisione critica della tesi di Giovanni Rotondi”, in Ferrary, Jean-Louis (ed.), Leges publicae. La legge nell'esperienza giuridica romana, Pavia 2012, 707-767. 
Mantovani, Dario, Legum multitudo. Die Bedeutung der Gesetze im römischen Privatrecht. Nachwort:Jakob F. Stagl, Juristenrecht und Gesetzesrecht, Berlin 2018.

Martin, Norbert, Die 'Compilatio Decretorum' des Kardinals Laborans. Eine Umarbeitung des gratianischen Dekrets aus dem 12. Jahrhundert (Ph.D. Thesis), Heidelberg 1994.

Martini, Remo, "Qualche osservazione a proposito della c.d. Epitome Gai", in Crifò, Giuliano and Stefano Giglio (eds.), Atti dell'Accademia romanistica costantiniana. XIV Convegno internazionale in memoria di Guglielmo Nocera, Naples 2003, 615-627.

Matthews, John F., "Interpreting the Interpretationes on the Breviarium", in Mathisen, Ralph W. (ed.), Law, Society, and Authority in Late Antiquity, Oxford 2001, 11-32.

Mazzacane, Aldo, "El jurista y la memoria", in Petit, Carlos (ed.), Pasiones del jurista. Amor, memoria, melancolía, imaginación, Madrid 1997, 75-102.

Meder, Stephan, Rechtsgeschichte. Eine Einführung, 6th ed., Cologne 2017.

Meyer, Christoph H.F., Die Distinktionstechnik in der Kanonistik des 12. Jahrhunderts. Ein Beitrag zur Wissenschaftsgeschichte des Hochmittelalters, Louvain 2000.

Meyer, Christoph H.F., "Spuren im Wald der Erinnerung. Zur Mnemotechnik in Theologie und Jurisprudenz des 12. Jahrhunderts", in Recherches de théologie et philosophie médiévales 67 (2000), 10-57.

Meyer, Christoph H.F., "Ordnung durch Ordnen. Die Erfassung und Gestaltung des hochmittelalterlichen Kirchenrechts im Spiegel von Texten, Begriffen und Institutionen", in Schneidmüller, Bernd and Stefan Weinfurter (eds.), Ordnungskonfigurationen im hohen Mittelalter, Ostfildern 2006, 303-411.

Meyer, Christoph H.F., "Kanonistik im Zeitalter von Absolutismus und Aufklärung: Spielräume und Potentiale einer Disziplin im Spannungsfeld von Kirche, Staat und Publizität", Max Planck Institute for European Legal History Research Paper Series No. 2018-6 (https://ssrn.com/abstract=2184754).

Michaud-Quantin, Pierre, "Les méthodes de la pastorale du XIIIe au XVe siècle", in Zimmermann, Albert (ed.), Methoden in Wissenschaft und Kunst des Mittelalters, Berlin 1970, 76-91.

Michel, Paul, "Wo das Lamm watet und der Elefant schwimmt. Eine Darstellung von Gregors des Großen Epistola dedicatoria zu den Moralia in Iob", in Herwig, Henriette, Irmgard Wirtz and Stefan Bodo Würffel (eds.), Lese - Zeichen. Semiotik und Hermeneutik in Raum und Zeit. Festschrift für Peter Rusterholz zum 65. Geburtstag, Tübingen 1999, 71-86.

Michelitsch, Antonius, Kommentatoren zur Summa Theologiae des hl. Thomas von Aquin, Graz 1924 (repr. Hildesheim 1981).

Montanos Ferrín, Emma, "A modo de consulta sobre la literatur jurídica del ius commune, III: summa angelica", in Anuario da Facultade de Dereito da Universidade da Coruña 8 (2004), 1114-1146.

Montorzi, Mario, “Processi di ‘standardizzazione’ testuale: margaritae, gemmae, tabulae. Un primo approccio di studio", in Montorzi, Mario, Processi istituzionali. Episodi 
di formalizzazione giuridica ed evenienze d'aggregazione istituzionale attorno ed oltro il feudo. Saggi e documenti, Padua 2005, 51-69.

Moore, Philip S., The Works of Peter of Poitiers Master in Theology and Chancellor of Paris (1193-1205), Washington, D.C. 1936.

Moschetti, Guiscardo, Primordi esegetici sulla legislazione longobarda nel sec. IX a Verona. Secondo il Cod. Vat. Lat. 5359, Spoleto 1954.

Mosiek, Ulrich, Die probati auctores in den Ehenichtigkeitsprozessen der S.R. Rota seit Inkraftreten des Codex Iuris Canonici, Freiburg 1959.

Mülke, Markus, Der Autor und sein Text. Die Verfälschung des Originals im Urteil antiker Autoren, Berlin 2008.

Müller, Jörg, "Heinrich v. Merseburg”, in Lexikon für Kirchen- und Staatskirchenrecht, vol. 2, Paderborn 2002, col. 232-233.

Müller, Wolfgang P., "Review of: Ch. Radding/A. Ciaralli, The Corpus iuris in the Middle Ages. Manuscripts and Transmission from the Sixth Century to the Juristic Revival, Leiden/Boston 2007", in Speculum 83 (2008), 1026-1027.

Munier, Charles, "La tradition manuscrite de l'Abrégé d'Hippone et le canon des Écritures des églises africaines", in Sacris erudiri 21 (1972/1973), 43-55 (reprint Munier, Charles, Vie conciliaire et collections canoniques en Occident, IV ${ }^{e}-X I I^{e}$ siècles, London $1987, \mathrm{v})$.

Musson, Anthony, "Seeing Justice: The Visual Culture of the Law and Lawyers", in Speer, Andreas and Guy Guldentops (eds.), Das Gesetz - The Law - La Loi, Berlin 2014, 711-721.

Nacci, Matteo, Origini, sviluppi e caratteri del jus publicum ecclesiasticum, Vatican City 2010.

Naz, Raoul, "Tabula alphabetica juris", in Dictionnaire de droit canonique, vol. 7, Paris 1965, col. $1145^{-1146 .}$

Nehlsen, Hermann, "Aktualität und Effektivität der ältesten germanischen Rechtsaufzeichnungen", in Classen, Peter (ed.), Recht und Schrift im Mittelalter, Sigmaringen 1977, 449-502.

Nehlsen, Hermann, "Alarich als Gesetzgeber. Zur Geschichte der Lex Romana Visigothorum", in Landwehr, Götz (ed.), Studien zu den germanischen Volksrechten. Gedächtnisschrift für Wilhelm Ebel, Frankfurt 1982, 143-203.

Nemo-Pekelman, Capucine, "How did the authors of the Breviarium Alaricianum work? The example of the laws on Jews", in Historical Research 86 (2013), 408-415.

Nörr, Dieter, Rechtskritik in der römischen Antike, Munich 1974.

Nörr, Dieter, “Zum Traditionalismus der römischen Juristen”, in Jakobs, Horst Heinrich, Brigitte Knobbe-Keuk, Eduard Picker and Jan Wilhelm (eds.), Festschrift für Werner Flume zum 7o. Geburtstag, vol. 1, Munich 1978, 153-19o.

Ocker, Christopher, "The Fusion of Papal Ideology and Biblical Exegesis in the Fourteenth Century", in Burrows, Mark Stephen (ed.), Biblical Hermeneutics in Historical 
Perspective. Studies in honor of Karlfried Froehlich, on his sixtieth birthday, Grand Rapids, MI 1991, 131-151.

Ocker, Christopher, Johannes Klenkok: A Friar's Life, c. 1310-1374, Philadelphia, PA 1993.

Ohst, Martin, Pflichtbeichte. Untersuchungen zum Bußwesen im Hohen und Späten Mittelalter, Tübingen 1995 .

Opelt, Ilona, "Epitome", in Reallexikon für Antike und Christentum, vol. 5, Stuttgart 1962, col. 944-973.

Otte, Gerhard, "Die Rechtswissenschaft", in Weimar, Peter (ed.), Die Renaissance der Wissenschaften im 12. Jahrhundert, Zurich 1981, 123-142.

Ourliac, Paul and Henri Gilles, La période post-classique (1378-150o), vol. 1: La problématique de l'époche. Les sources (Histoire du Droit et des Institutions de l'Église en Occident, vol. 13), Paris 1971.

Parkes, Malcolm B., "The Influence of the Concepts of Ordinatio and Compilatio on the Development of the Book", in Alexander, Jonathan J.G. and Margaret T. Gibson (eds.), Medieval Learning and Literature. Essays presented to Richard William Hunt, Oxford 1976, 115-141.

Pennington, Kenneth, "Decretal Collections", in Hartmann, Wilfried and Kenneth Pennington (eds.), The History of Medieval Canon Law in the Classical Period, 1140-1234. From Gratian to the Decretals of Pope Gregory IX, Washington, D.C. 2008, 293-317.

Pennington, Kenneth and Wolfgang Müller, "The Decretists: The Italian School", in Hartmann, Wilfried and Kenneth Pennington (eds.), The History of Medieval Canon Law in the Classical Period, 1140-1234. From Gratian to the Decretals of Pope Gregory $I X$, Washington, D.C. 2008, 121-173.

Périès, George, La Faculté de droit dans l'ancienne Université de Paris (1160-1793), Paris 1890.

Prinz, Franziska, Der Bildgebrauch in gedruckten Rechtsbüchern des 15. bis zum Ausgang des 18. Jahrhunderts, Hamburg 2006.

Radding, Charles A. and Antonio Ciaralli, The Corpus Iuris Civilis in the Middle Ages. Manuscripts and transmission from the sixth century to the juristic revival, Leiden 2007.

Raible, Wolfgang, "Arten des Kommentierens - Arten der Sinnbildung - Arten des Verstehens. Spielarten der generischen Intertextualität", in Assmann, Jan and Burkhard Gladigow (eds.), Text und Kommentar, Munich 1995, 51-73.

Rambaud-Buhot, Jacqueline, "Les divers types d'abrégés du Décret de Gratien. De la table au commentaire", in Recueil de travaux offerts à M. Clovis Brunel membre de l'Institut, directeur honnoraire de l'École des chartes, vol. 2, Paris 1955, 397-411.

Rambaud-Buhot, Jacqueline, "L'Abbreviatio Decreti d'Omnebene", in Kuttner, Stephan and Kenneth Pennington (eds.), Proceedings of the Sixth International Congress of Medieval Canon Law. Berkeley, California, 28 July-2 August 1980, Vatican City 1985, 93-107. 
Richter, Aemilius Ludwig, Beiträge zum Preussischen Kirchenrechte, ed. Hinschius, Paul, Leipzig 1856.

Rivers, Kimberly A., "Remembering Canon and Civil Law around 140o", in Nottingham Medieval Studies 56 (2012), 265-280.

Rivers, Kimberly A., "Learning and Remembering Canon Law in the Fifteenth Century: The Ars et doctrina studendi et docendi of Juan Alfonso de Benavente", in Sharp, Tristan (ed.), From Learning to Love. Schools, Law, and Pastoral Care in the Middle Ages. Essays in Honour of Joseph W. Goering, Toronto 2017, 266-29o.

Röhl, Klaus F., “(Juristisches) Wissen über Bilder vermitteln”, in Dausendschön-Gay, Ulrich, Christine Domke and Sören Ohlhus (eds.), Wissen in (Inter-)Aktion. Verfahren der Wissensgenerierung in unterschiedlichen Praxisfeldern, Berlin 2010, 281-311.

Rotondi, Giovanni, Leges publicae populi romani. Elenco cronologico con una introduzione sull' attività legislatoria dei comizi romani. Estratto della Enciclopedia Giuridica Italiana, Milan 1912 (repr. Hildesheim 1966).

Roumy, Franck, “Un abrégé inconnu du Décret de Gratien”, in Bontems, Claude (ed.), Nonagesimo anno. Mélanges en hommage à Jean Gaudemet, Paris 1999, 501-519.

Rouse, Mary A., "Florilegia", in Dictionary of the Middle Ages, vol. 5, New York 1985, 109-110.

Rouse, Mary A. and Richard H. Rouse, "La naissance des index", in Chartier, Roger and Henri-Jean Martin (eds.), Histoire de l'édition française, vol. 1, Paris 1989, 95-108.

Rouse, Richard H. and Mary A. Rouse, "Statim invenire. Schools, Preachers, and New Attitudes to the Page", in Benson, Robert L. and Giles Constable (eds.), Renaissance and Renewal in the Twelfth Century, Cambridge, MA 1982, 201-225.

Ruiz Jurado, Manuel, "De las Constituciones S.J. al Epítome”, in McCoog, Thomas M. (ed.), Ite inflammate omnia. Selected historical papers from conferences held at Loyola and Rome in 2006, Rome 2010, 129-147.

Sánchez-Moreno Ellart, Carlos, “Law, 'vulgar' ”, in The Encyclopedia of Ancient History, vol. 7, Malden, MA 2013, 3975-3978.

Santucci, Gianni, "Legum inopia e diritto privato. Riflessioni intorno ad un recente contributo", in Studia et documenta historiae et iuris 8o (2014), 373-393.

Schadt, Hermann, Die Darstellungen der Arbores Consanguinitatis und der Arbores Affinitatis. Bildschemata in juristischen Handschriften, Tübingen 1982.

Scherer, Rudolf von, Handbuch des Kirchenrechtes, vol. 1, Graz 1886.

Schiller, Arthur A., Roman Law. Mechanisms of Development, The Hague 1978.

Schindler, Karl-Heinz, Justinians Haltung zur Klassik. Versuch einer Darstellung an Hand seiner Kontroversen entscheidenden Konstitutionen, Cologne 1966.

Schmidt-Wiegand, Ruth, "Rechtsverse", in Handwörterbuch zur deutschen Rechtsgeschichte, vol. 4, Berlin 1990, col. 410-415.

Schmidt-Wiegand, Ruth, "Populärjurisprudenz zwischen Artesliteratur und Richterlichem Clagspiegel", in Wich-Reif, Claudia (ed.), Strukturen und Funktionen in 
Gegenwart und Geschichte. Festschrift für Franz Simmler zum 65. Geburtstag, Berlin 2007, 537-554.

Schmitt, Cl., "Jacques Ungarelli", in Catholicisme: hier, auhourd'hui, demain, vol. 6, Paris 1967, col. $287-288$.

Schmoeckel, Mathias, "Beichtstuhljurisprudenz", in Handwörterbuch zur deutschen Rechtsgeschichte, vol. 1, 2nd ed., Berlin 2008, col. 505-508.

Schönberger, Rolf, Was ist Scholastik?, Hildesheim 1991.

Schott, Clausdieter, "Pactus, Lex und Recht", in Hübener, Wolfgang (ed.), Die Alemannen in der Frühzeit, Bühl 1974, 135-168.

Schulte, Johann Friedrich von, "Zur Geschichte der Literatur über das Dekret Gratians. Dritter Beitrag", in Sitzungsberichte der kaiserlichen Akademie der Wissenschaften Wien. Philosophisch-historische Klasse 65 (1870), 21-76.

Schulte, Johann Friedrich von, Die Geschichte der Quellen und Literatur des canonischen Rechts, vol. 2, Stuttgart 1877 (repr. Graz 1956).

Schulte, Johann Friedrich von, Die Geschichte der Quellen und Literatur des canonischen Rechts, vol. 3.1 \& vol. 3.2-3, Stuttgart 188o (repr. Graz 1956).

Schulz, Fritz, Principles of Roman Law, Oxford 1936.

Schulz, Fritz, History of Roman Legal Science, 2nd ed., Oxford 1953.

Schwerin, Claudius von, "Die Epitome Guelferbytana zum Breviarium Alaricianum", in Atti del Congresso internazionale di diritto romano (Bologna e Roma XVII-XXVII Aprile MCMXXXIII), vol. 1, Bologna 1934, 167-196.

Schwind, Fritz, Zur Frage der Publikation im Römischen Recht mit Ausblicken in das altgriechische und ptolemäische Rechtsgebiet, 2nd ed., Munich 1973.

Seckel, Emil, Das römische Recht und seine Wissenschaft im Wandel der Jahrhunderte. Rede zum Antritt des Rektorates der Friedrich-Wilhelms-Universität in Berlin gehalten in der Aula am 15. Oktober 1920, Berlin 1921.

[Seckel, Emil,] "Die Vorträge Emil Seckels in der Berliner Mittwochs-Gesellschaft (Teil 3, X.-XVI.) [...], herausgegeben von Werner Schhubert", in Zeitschrift der SavignyStiftung für Rechtsgeschichte. Romanistische Abteilung 123 (2006), 349-374.

Sedano, Joaquín, "Breviarium", in Diccionario general de derecho canónico, vol. 1, Cizur Menor 2012, 753-754.

Sieben, Hermann Josef, Die katholische Konzilsidee von der Reformation bis zur Aufklärung, Paderborn 1988.

Sieben, Hermann Josef, Kleines Lexikon zur Geschichte der Konzilsidee, Paderborn 2018.

Siems, Harald, "Zu Problemen der Bewertung frühmittelalterlicher Rechtstexte. Zugleich eine Besprechung von R. Kottje, Zum Geltungsbereich der Lex Alamannorum", in Zeitschrift der Savigny-Stiftung für Rechtsgeschichte. Germanistische Abteilung 106 (1989), 291-305.

Siems, Harald, Handel und Wucher im Spiegel frühmittelalterlicher Rechtsquellen, Hannover 1992. 
Siems, Harald, "Adsimilare. Die Analogie als Wegbereiterin zur mittelalterlichen Rechtswissenschaft", in Herbers, Klaus (ed.), Europa an der Wende vom 11. zum 12. Jahrhundert. Beiträge zu Ehren von Werner Goez, Stuttgart 2001, 143-170.

Sirks, A.J.B., The Theodosian Code. A study, Friedrichsdorf 2007.

Soliva, Claudio, "Römisches Recht in Churrätien", in Jahrbuch der HistorischAntiquarischen Gesellschaft von Graubünden 116 (1986), 189-206.

Speer, Heino, "Verstehenshilfen zum geschriebenen Recht - Medienwandel als Chance. Eine Skizze", in Speer, Heino (ed.), Wort - Bild - Zeichen. Beiträge zur Semiotik im Recht, Heidelberg 2012, 225-252.

Spitz, Hans-Jörg, Die Metaphorik des geistigen Schriftsinns. Ein Beitrag zur allegorischen Bibelauslegung des ersten christlichen Jahrtausends, Munich 1972.

Spruit, Johannes E., "Visions fugitives", in Feenstra, Robert, Arthur S. Hartkamp, Johannes E. Spruit, Pieter Johannes Sijpesteijn and Laurens C. Winkel (eds.), Collatio iuris romani. Études dédiées à Hans Ankum à l'occasion de son 65 e anniversaire, vol. 2, Amsterdam 1995, 489-497.

Stagl, Jakob Fortunat, "Die Bedeutung von leges publicae im Römischen Recht: Der Beitrag Mantovanis zur „legum multitudo“ und die Frage der Privatautonomie bei den Römern", in Zeitschrift der Savigny-Stiftung. Romanistische Abteilung 133 (2016), $445^{-458 .}$

Stein, Robert, "Alte und neue Übersichtstafeln. Ein Beitrag zur Geschichte der Unterrichtsmittel und eine Anregung zu erneuter Verwendung", in Deutsche Geschichtsblätter 17 (1916), 167-192, 226-248.

Stickler, Alphonsus M., Historia iuris canonici latini. Institutiones academicae, vol. 1: Historia fontium, Turin 195 o.

Stintzing, Roderich, Geschichte der populären Literatur des römisch-kanonischen Rechts in Deutschland am Ende des fünfzehnten und im Anfang des sechszehnten Jahrhunderts, Leipzig 1867 .

Stintzing, Roderich, Geschichte der deutschen Rechtswissenschaft, vol. 1, Munich 188 o.

Stolleis, Michael, "Vom Verschwinden verbrauchten Rechts", in Kiesow, Rainer Maria, Regina Ogorek and Spiros Simitis (eds.), Summa. Dieter Simon zum 7o. Geburtstag, Frankfurt 2005, 539-558.

Stolleis, Michael, "Corpus Iuris Civilis par cœur", in Haferkamp, Hans-Peter and Tilman Repgen (eds.), Usus modernus pandectarum. Römisches Recht, Deutsches Recht und Naturrecht in der Frühen Neuzeit. Klaus Luig zum 7o. Geburtstag, Cologne 2007, $245^{-269 .}$

Stolleis, Michael, "Vom Umgang mit veralteten Büchern, oder: Mit den Toten sprechen", in Nolte, Jakob, Ralf Poscher and Henner Wolter (eds.), Die Verfassung als Aufgabe von Wissenschaft, Praxis und Öffentlichkeit. Freundesgabe für Bernhard Schlink zum 70. Geburtstag, Heidelberg 2014, 15-24. 
Taliadoros, John, Law and Theology in Twelfth-Century England. The Works of Master Vacarius (c. 1115/20-c. 1200), Turnhout 2006.

Tardif, Ernest-Joseph, “Un abrégé juridique des Étymologies d'Isidore de Séville”, in Tardif, Ernest-Joseph (ed.), Mélanges Julien Havet. Recueil des travaux d'érudition dédiés à la mémoire de Julien Havet (1853-1893), Paris 1895, 659-681.

Thesaurus linguae Latinae, vol. 5.2, Leipzig 1931-1953.

Trump, Dominik, "Römisches Recht in Reims: Ein Exzerpt aus der Epitome Aegidii in der Handschrift Mailand, Biblioteca Ambrosiana, A. 46 inf.", in Zeitschrift der Savigny-Stiftung für Rechtsgeschichte. Romanistische Abteilung 133 (2016), $322-371$.

Trusen, Winfried, Anfänge des gelehrten Rechts in Deutschland. Ein Beitrag zur Geschichte der Frührezeption, Wiesbaden 1962.

Trusen, Winfried, "Forum internum und gelehrtes Recht im Spätmittelalter. Summae confessorum und Traktate als Wegbereiter der Rezeption", in Zeitschrift der SavignyStiftung für Rechtsgeschichte. Kanonistische Abteilung 57 (1971), 83-126.

Trusen, Winfried, "Zur Bedeutung des geistlichen Forum internum und externum für die spätmittelalterliche Gesellschaft", in Zeitschrift der Savigny-Stiftung für Rechtsgeschichte. Kanonistische Abteilung 76 (1990), 254-285.

Ullmann, Walter, "The Paleae in Cambridge Manuscripts of the Decretum", in Studia Gratiana 1 (1953), 161-216.

Van Hove, Alphonse, Prolegomena (Commentarium Lovaniense in Codicem Iuris Canonici), vol. 1.1, 2nd ed., Mechlin 1945.

Varga, Csaba, Codification as a Socio-Historical Phenomenon, Budapest 1991.

Vetulani, Adam and Wacław Uruszczak, "L'œuvre d'Omnebene dans le MS 602 de la Bibliothèque municipale de Cambrai", in Kuttner, Stephan (ed.), Proceedings of the Fourth International Congress of Medieval Canon Law. Toronto, 21-25 August 1972, Vatican City 1976, 11-26.

Viora, Mario E., "La Summa Angelica", in Bollettino storico-bibliografico subalpino 38 (1936), 443-451.

Waelkens, Laurent, "Le Décret de Gratien, un florilège de textes juridiques des années 1130", in Ceulemans, Reinhart and Pieter de Leemans (eds.), On Good Authority. Tradition, Compilation and the Construction of Authority in Literature from Antiquity to the Renaissance, Turnhout 2015, 245-262.

Wei, John C., “The Later Development of Gratian's Decretum”, in Goering, Joseph, Stephan Dusil and Andreas Thier (eds.), Proceedings of the Fourteenth International Congress of Medieval Canon Law. Toronto, 5-11 August 2012, Vatican City 2016, 149-159.

Weigand, Rudolf, "Die frühen kanonistischen Schulen und die Dekretabbreviatio Omnebenes", in Archiv für katholisches Kirchenrecht 155 (1986), 72-91. 
Weigand, Rudolf, "Die Dekretabbreviatio 'Quoniam egestas' und ihre Glossen”, in Aymans, Winfried, Anna Egler and Joseph Listl (eds.), Fides et ius. Festschrift für Georg May zum 65. Geburtstag, Regensburg 1991, 249-265.

Weigand, Rudolf, 'Die Dekretabbreviatio 'Exceptiones ecclesiasticarum regularum' und ihre Glossen”, in Alzati, Cesare (ed.), Cristianità ed Europa. Miscellanea di studi in onore di Luigi Prosdocimi, Cesare Alzati, vol. 1,2, Rome 1994, 511-529.

Weimar, Peter, “Die legistische Literatur der Glossatorenzeit”, in Coing, Helmut (ed.), Handbuch der Quellen und Literatur der neueren europäischen Privatrechtsgeschichte, vol. 1: Mittelalter (1100-150o). Die gelehrten Rechte und die Gesetzgebung, Munich 1973, 129-26o.

Weiß, Egon, "Schwund und Konservierung im römischen juristischen Schrifttum", in Zeitschrift der Savigny-Stiftung für Rechtsgeschichte. Romanistische Abteilung 67 (1950), 501-511.

Wejwoda, Marek, Spätmittelalterliche Jurisprudenz zwischen Rechtspraxis, Universität und kirchlicher Karriere. Der Leipziger Jurist und Naumburger Bischof Dietrich von Bocksdorf (ca.1410-1466), Leiden 2012.

Wesjohann, Achim, "Simplicitas als franziskanisches Ideal und der Prozeß der Institutionalisierung des Minoritenordens", in Melville, Gert and Jörg Oberste (eds.), Die Bettelorden im Aufbau. Beiträge zu Institutionalisierungsprozessen im mittelalterlichen Religiosentum, Munster 1999, 107-167.

Wieacker, Franz, Textstufen klassischer Juristen, Göttingen 1960.

Wieacker, Franz, Römische Rechtsgeschichte. Zweiter Abschnitt: Die Jurisprudenz vom frühen Prinzipat bis zum Ausgang der Antike im weströmischen Reich und die oströmische Rechtswissenschaft bis zur justinianischen Gesetzgebung. Ein Fragment, ed. Wolf, Joseph Georg, Munich 2006.

Winroth, Anders, The Making of Gratian's Decretum, Cambridge 2000.

Winroth, Anders, "Where Gratian Slept: The Life and Death of the Father of Canon Law", in Zeitschrift der Savigny-Stiftung für Rechtsgeschichte. Kanonistische Abteilung 99 (2013), 105-128.

Winter, Steven L., "A Clearing in the Forest", in Metaphor and Symbolic Activity 10 (1995), 223-245.

Wittekind, Susanne, "Überlegungen zur Verwendung graphischer Marginalien in Rechtshandschriften ausgehend von Dom-Handschrift 127", in Horst, Harald (ed.), Mittelalterliche Handschriften der Kölner Dombibliothek. Siebtes Symposion der Diözesan- und Dombibliothek Köln zu den Dom-Manuskripten (25. und 26. November 2016), Cologne 2018, 83-114.

Wölfflin, Eduard, "Epitome", in Archiv für lateinische Lexikographie und Grammatik 12 (1902), 333-344.

Worstbrock, Franz Josef, "Libri pauperum. Zu Entstehung, Struktur und Gebrauch einiger mittelalterlicher Buchformen der Wissensliteratur seit dem 12. Jahrhundert", 
in Meier, Christel, Dagmar Hüpper and Hagen Keller (eds.), Der Codex im Gebrauch, Munich 1996, 41-6o.

Zapp, Hartmut, "Abbreviationes", in Lexikon des Mittelalters, vol. 1, Munich 1980, col. 16 . 